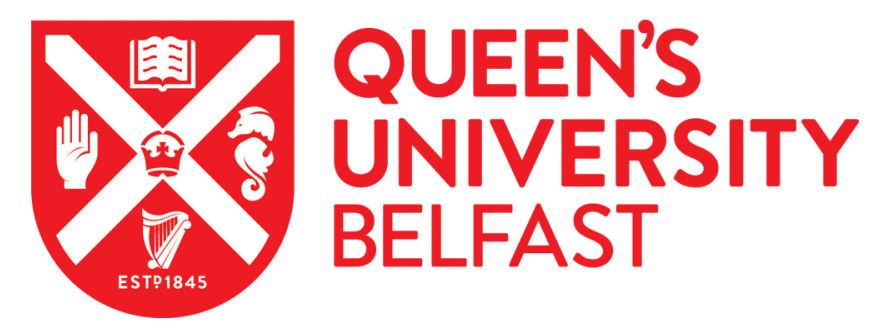

\title{
Interventions to support family caregivers of people with advanced dementia at the end of life in nursing homes: A mixed-methods systematic review
}

Gonella, S., Mitchell, G., Bavelaar, L., Conti, A., Vanalli, M., Basso, I., \& Cornally, N. (2022). Interventions to support family caregivers of people with advanced dementia at the end of life in nursing homes: A mixedmethods systematic review. Palliative Medicine, 36(2), 268-291. https://doi.org/10.1177/02692163211066733

Published in:

Palliative Medicine

Document Version:

Peer reviewed version

Queen's University Belfast - Research Portal:

Link to publication record in Queen's University Belfast Research Portal

Publisher rights

Copyright 2021, the Authors.

This work is made available online in accordance with the publisher's policies. Please refer to any applicable terms of use of the publisher.

\section{General rights}

Copyright for the publications made accessible via the Queen's University Belfast Research Portal is retained by the author(s) and / or other copyright owners and it is a condition of accessing these publications that users recognise and abide by the legal requirements associated with these rights.

Take down policy

The Research Portal is Queen's institutional repository that provides access to Queen's research output. Every effort has been made to ensure that content in the Research Portal does not infringe any person's rights, or applicable UK laws. If you discover content in the Research Portal that you believe breaches copyright or violates any law, please contact openaccess@qub.ac.uk. 


\section{Title}

Interventions to support family caregivers of people with advanced dementia at the end of life in nursing homes: a mixed-methods systematic review

\section{Running head}

Support advanced dementia family caregivers

\section{Authors}

Silvia Gonella ${ }^{\mathrm{a}, \mathrm{b}}, \mathrm{RN}, \mathrm{MSc}, \mathrm{PhD}$; Gary Mitchellc ${ }^{\mathrm{c}}$ RN, MSc, PhD; Laura Bavelaard ${ }^{\mathrm{d}}, \mathrm{MSc}, \mathrm{PhDs}$; Alessio Conti ${ }^{a}, \mathrm{RN}, \mathrm{MSc}, \mathrm{PhD}$; Mariangela Vanallie, RN, MSc, PhDs; Ines Basso ${ }^{\mathrm{f}}, \mathrm{RN}, \mathrm{MSc}$; Nicola Cornally ${ }^{\mathrm{g}} \mathrm{RN}, \mathrm{MSc}, \mathrm{PhD}$

\section{Authors affiliation}

${ }^{a}$ Department of Public Health and Pediatrics, University of Torino, via Santena 5 bis, 10126 Torino, Italy.

b Azienda Ospedaliero Universitaria Città della Salute e della Scienza di Torino, Corso Bramante 8890, 10126 Torino, Italy.

c School of Nursing \& Midwifery, Queen's University Belfast, Medical Biology Centre, 97 Lisburn Road, Belfast, BT97BL, Northern Ireland.

${ }^{\mathrm{d}}$ Department of Public Health and Primary Care, Leiden University Medical Center, Hippocratespad 21, 2300 RC Leiden, The Netherlands

${ }^{\mathrm{e}}$ Department of Biomedicine and Prevention, University of Roma Tor Vergata, Via Montpellier 1, 00133 Roma, Italy.

${ }_{\mathrm{f}}^{\mathrm{f}}$ School of Nursing, Azienda Ospedaliera "SS Antonio e Biagio e Cesare Arrigo", Via Venezia 16, 15121, Alessandria, Italy.

g Catherine McAuley School of Nursing and Midwifery, University College Cork, Brookfield Health Sciences Complex College Road Cork, T12 AK54, Cork, Ireland.

\section{Corresponding author}

Silvia Gonella, RN, $\mathrm{PhD}$

Department of Public Health and Pediatrics, University of Torino

Via Santena 5 bis, 10126 Torino, Italy

Azienda Ospedaliero Universitario Città della Salute e della Scienza di Torino

Corso Bramante 88-90, 10126 Torino, Italy 
Phone 390110915831

Fax 390112365831

Email silvia.gonella@unito.it

\title{
Word count : 4995
}

\begin{abstract}
Auhtorship
Authors of Manuscript: AC, IB, GM, LB, MV, NC and SG

GM, IB, and SG contributed to the conception and design of the work; IB, GM, LB, MV and SG extracted and analysed the data. All authors contributed to interpret data and draft the manuscript. All authors critically revised the manuscript, agree to be fully accountable for ensuring the integrity and accuracy of the work, and read and approved the final manuscript.
\end{abstract}




\begin{abstract}
Background: Most people with dementia transition into nursing homes as their disease progresses. Their family caregivers often continue to be involved in their relative's care and experience high level of strain at the end of life.

Aim: To gather and synthesize information on interventions to support family caregivers of people with advanced dementia at the end of life in nursing homes and provide a set of recommendations for practice.

Design: Mixed-Methods Systematic Review (PROSPERO no. CRD42020217854) with convergent integrated approach.

Data Sources: Five electronic databases were searched from inception in November 2020. Published qualitative, quantitative and mixed-method studies of interventions to support family caregivers of people with advanced dementia at the end of life in nursing home were included. No language or temporal limits were applied.

Results: In all, 11 studies met the inclusion criteria. Data synthesis resulted in three integrated findings: (i) healthcare professionals should engage family caregivers in ongoing dialogue and provide adequate time and space for sensitive discussions; (ii) end-of-life discussions should be faceto-face and supported by written information whose timing of supply may vary according to family caregivers' preferences and the organizational policies and cultural context; and (iii) family caregivers should be provided structured psychoeducational programmes tailored to their specific needs and/or regular family meetings about dementia care at the end of life.
\end{abstract}

Conclusion: The findings provide useful information on which interventions may benefit family caregivers of people with advanced dementia at the end of life and where, when, and how they should be provided.

Keywords: Education, dementia, family, health communication, nursing homes, systematic review, palliative care, terminal care 


\section{Key statements}

\section{What is already known about the topic?}

- Several people with advancing dementia move permanently into nursing homes due to increasing disability and dependence.

- Family caregivers of people with dementia experience the highest level of strain when their relative's death is nearing and they often live in nursing homes.

- Family caregivers of people with dementia at the end of life have specific information and support needs related to the emotional impact of dementia and their decision-making role.

- Supporting family caregivers during the end-of-life stage prepares them emotionally for their relative's death and helps them cope with their caregiving role.

\section{What this paper adds?}

- This paper focuses on support for family caregivers of people with dementia at end of life in nursing homes while most literature addresses family caregivers of people living in the community or during the transition to the nursing home.

- Ongoing discussions between family caregivers and healthcare professionals facilitates partnership, promotes informed and shared decisions, is a source of emotional support, and essential to family caregivers' empowerment.

- Preferred timing of information provision about care options in advanced dementia is highly influenced by individual preferences and context.

- Psychoeducational programmes and regular meetings with trusted healthcare professionals tailored to family caregivers' specific and changing emotional and information needs can promote self-care and empowerment.

- Interacting with peers and healthcare professionals independent from the nursing home or experienced in psychological care may help family caregivers to identify their dementia education needs, manage distress and develop problem-solving skills.

\section{Implications for practice, theory or policy}

- Interventions to support family caregivers of people with advanced dementia at the end of life should include timely and ongoing face-to-face discussions complemented by written information and structured psychoeducational programmes which provide targeted socioemotional care in addition to tailored information, while involving a multiprofessional team and possibly peers. 
- Goverments must acknowledge support of family caregivers of people with advanced dementia as a public health priority and invest resources in programs to provide them evidence-based support.

- Optimal support for family caregivers of people with advanced dementia at the end of life can promote their empowerment resulting in improved self-care attitudes and greater engagement in shared decisions for their relative's end-of-life care.

- Further research could assess how peer support and professional support for family caregivers of people with dementia in the nursing home may complement each other. 


\section{Introduction}

Dementia is a cluster of terminal neurodegenerative disorders characterized by progressive and irreversible cognitive and functional decline, particularly among older adults. ${ }^{1}$ It is estimated that around 50 million people currently have dementia worldwide, and there are nearly 10 million new cases every year. ${ }^{2}$ The total number of people with dementia is projected to reach 82 million in 2030 and 152 in 2050..$^{2,3}$ Most people with dementia and their family caregivers desire that they remain at home for as long as possible ${ }^{4}$ and there is growing research about interventions which aim to postpone transition to nursing homes. ${ }^{5,6}$ These facilities are also known as aged-care or long-term care homes and provide nursing care and assistance in activities of daily living in addition to room and board. ${ }^{7}$ However, about $75 \%$ of people with dementia move permanently into nursing homes at some point of the disease trajectory due to increasing disability and dependence. ${ }^{4,8}$ This means that healthcare professionals working in nursing homes increasingly care for people living with dementia and their family caregivers. ${ }^{9}$

Family caregivers of people with dementia are at increased risk of burden, stress, and depression. ${ }^{10}$,

${ }^{11}$ Despite literature shows that some family caregivers experience less clinically significant burden and depressive symptoms once their relative moves to a nursing home, particularly for those who lived with the person with advanced dementia in the community as their caregiving responsibilities decrease, ${ }^{12}$ often the burden of caregiving persists after a relative moves to a nursing home ${ }^{13,14}$ and levels of strain increase near the end of life. ${ }^{15}$ Indeed, most family caregivers continue to occupy a pivotal position in the decision-making process as surrogate decision-maker after their relative's move to the nursing home. ${ }^{16,17}$ This suggests that entering a nursing home does not necessarily signal the end of caregiving but rather identifies a new phase of the caregiving trajectory, which may be as challenging as or even more than caregiving at home. ${ }^{18}$ Therefore, family caregivers of people with dementia need continuous support, from a relative's move to a nursing home to realign their role ${ }^{19}$ until death since high level of family caregivers' anticipatory grief was suggested to be associated with worse well-being outcomes post-death. ${ }^{20,21}$

The World Health Organization recognizes support for family caregivers of people with advanced dementia as a public health priority. ${ }^{2}$ Particularly, family caregivers need both guidance in taking decisions for their relative's end-of-life care ${ }^{22}$ and social and emotional support. ${ }^{23}$

Supporting family caregivers during the end-of-life stage may be particularly worthy not only with respect to offering them resources to tackle their strain thus avoiding prolonged or complicated grief, ${ }^{20,}{ }^{24}$ but also to help them cope with their caregiving role as a best interest decision-maker on behalf of their relative who may lack capacity. ${ }^{23}$ Caring for family caregivers by providing information about the course of dementia and treatment options as well as attending to their 
emotional, psychosocial, and spiritual needs should be planned for throughout the overall disease trajectory. ${ }^{23}$ However, literature mainly focuses on the support that family caregivers of people with dementia receive when they are still at home ${ }^{25}$ and during the transition towards the nursing home, ${ }^{26}$, 27 while knowledge about the support in taking challenging decisions about goals of care and treatments during the final weeks or a few months of their relative's life (hereafter end of life) is poor and fragmented. Therefore, this literature review aims to gather and synthesize information on interventions to support family caregivers of people with advanced dementia at the end of their relative's life in nursing homes and provide a set of recommendations for practice.

The central question driving this research is: what interventions support family caregivers of people with advanced dementia at end of life in nursing homes?

\section{Methods}

\section{Design}

A systematic review according to the Joanna Briggs Institute methodology for Mixed-Methods Systematic Review was performed. ${ }^{28}$

This review has been reported in accordance with the Synthesis Without Meta-analysis (SWiM) guidelines $^{29}$ (Appendix 1) and Preferred Reporting Items for Systematic Reviews and Meta-Analyses (PRISMA) guidelines ${ }^{30}$ (Figure 1) to enhance the quality and transparency of reporting. The review protocol was registered on PROSPERO register of systematic reviews on 5 November 2020 (registration number CRD42020217854), available at https://www.crd.york.ac.uk/prospero/display_record.php?ID=CRD42020217854.

\section{Search Strategy}

A three-step search strategy was employed: 1. an explorative search on PubMed and CINAHL EBSCO was conducted in October 2020 followed by an analysis of title, abstract and the index terms to identify the most appropriate keywords; 2. five databases (PubMed, CINAHL EBSCO, PsychInfo EBSCO, Joanna Briggs Institute, and Scopus) were searched from inception on November $5^{\text {th }} 2020$. Searches employed both controlled vocabularies and free terms, without temporal or language limits. Search strategies were adapted for each database (Appendix 2); 3. the references of included articles were screened to identify further relevant publications.

\section{Inclusion and exclusion criteria}




\section{Population}

Studies were included if they focused on any type of interventions aimed at supporting family caregivers of people with advanced dementia at the end of life in nursing homes by promoting their awareness and resilience. End of life was defined as the final weeks or a few months of a relative's life. ${ }^{31}$

Interventions delivered at the organizational level (e.g., care coordination program, respite program) or at the societal/policy level (e.g., payment rules, waiver programs, direct services to caregivers of people with dementia, policies regarding unpaid or paid leave for caregivers) as well as residentoriented support interventions were excluded. Interventions at the organizational level were excluded since they are usually delivered in community settings and aimed at relieving caregiving responsibilities on a temporary or periodic basis during the disease trajectory, rather than promoting family caregivers' awareness and resilience, thus not providing an ongoing support for the end-oflife phase. Interventions at the societal/policy level were excluded since public support may widely vary across jurisdictions, thus preventing from providing generalizable recommendations. Caregiveroriented support interventions as part of multi-faceted programmes were included only when caregiver-oriented support interventions were clearly recognizable and assessable.

Family caregivers of people with advanced dementia were defined as the relative, partner, close friend, or neighbor who provides assistance in activities of daily living, or social or emotional support to the person with dementia, or assumes an advocacy role. ${ }^{32}$

\section{Phenomena of interest}

The review considered studies that investigated all forms of interventions delivered at the caregiver level (e.g., educational, psychosocial, and psychological interventions) which are employed to support family caregivers of people with advanced dementia at the end of life in nursing homes.

\section{Context}

Studies merging caregiver-oriented support interventions across different settings (i.e. home, public hospital, hospice, private hospital and assisted living) were included only when the results related to the nursing homes were clearly distinguishable. Nursing home was defined as a facility that provides room and board, as well as management of chronic medical conditions and nursing care and interventions with activities of daily living for patients who are physically and/or cognitively impaired. ${ }^{7}$ 


\section{Types of studies}

Quantitative, qualitative and mixed methods studies were considered. Quantitative studies included cross-sectional studies, pre-post studies, clinical trials, controlled clinical trials, and randomized controlled trials; qualitative studies included qualitative descriptive, phenomenology, grounded theory, ethnography, case study, and action research design. Mixed methods studies were considered if data from the quantitative or qualitative components were clearly recognizable. When studies were quantitative according to the study authors but also reported qualitative data, the study was considered "quantitative" but both qualitative and quantitative data were included.

Theses, dissertations, abstracts in proceedings and other papers published in non-peer-reviewed publications (e.g. government working papers) as well as research protocols were excluded.

\section{Screening and study selection}

All identified articles were loaded into EndNote X9 (Clarivate Analytics, PA, USA) and duplicates removed. Titles, abstracts, and finally full texts, were screened by two independent reviewers for assessment against the inclusion and exclusion criteria.

\section{Assessment of methodological quality}

The selected papers were independently assessed by two reviewers for methodological validity using Joanna Briggs Institute critical appraisal tools for survey designs reporting frequencies/proportions, ${ }^{33}$ randomized controlled trials, ${ }^{34}$ qualitative studies, ${ }^{35}$ and case reports. ${ }^{36}$ Details of the items contained in each critical appraisal tool are reported in Appendix 3. No studies were excluded on the basis of methodological quality.

\section{Data extraction}

Two independent reviewers extracted data including author(s), year, type of study (i.e., quantitative, qualitative, and mixed methods), methodology (e.g., cohort, phenomenology), geographical context and other context-related information, number and characteristics of participants, phenomena of interest, data collection, data analysis, and main findings according to the Joanna Briggs Institute mixed methods data extraction form following a convergent integrated approach. ${ }^{28}$ Moreover, details regarding the interventions delivered to support family caregivers were extracted, when available.

Quantitative data comprised of averages or percentages that profiled the sample as well as all relationships between study variables and outcome. Qualitative data comprised of themes or subthemes relevant to the review question with corresponding illustrations (i.e., participants' direct 
quotations or the exact words of the authors), which were assigned a level of credibility based on the congruency of the finding with supporting data: unequivocal (evidence beyond reasonable doubt); credible (plausible in light of the data and theoretical framework); or unsupported (no relationship between findings and data). ${ }^{37}$ Only findings unequivocal and credible were included in the synthesis. Each finding was identified by an alphanumeric code (e.g. A1, A2, B1, ...). Each letter corresponded to a study and each number to a unique finding. The progressive letters indicate the order of study inclusion in the review, while the progressive numbers indicate the order of findings in the original article (Table 1, Table 2, Table 3).

\section{Data transformation}

The quantitative data was converted into 'qualitized data' because codifying quantitative data is less error-prone than attributing numerical values to qualitative data. ${ }^{28}$ Qualitized data comprised textual descriptions or narrative interpretation of the quantitative results (e.g., 'Undergoing some type of educational programme as a significant factor in predicting less role overload, less stress related to the caregiving situation, more frequent use of reframing, and greater competence dealing with healthcare professionals' is the transformation identified from a three-arm randomized study aimed at testing the efficacy of a psychoeducational programme compared to a comparison programme or no programme in enhancing mental health of women caregivers of a relative with dementia living in a long-term care setting that used prediction analysis). ${ }^{38}$

\section{Data synthesis and integration}

The convergent integrated approach to synthesis according to the Joanna Briggs Institute methodology for Mixed-Methods Systematic Review, ${ }^{28}$ based on previous work of Sandelowski ${ }^{39}$ and Hong ${ }^{40}$ was adopted. Qualitized data were assembled with the qualitative data directly extracted from qualitative studies. Assembled data were categorized and pooled together based on similarity in meaning (i.e., a category may integrate two or more types of data: qualitative data, qualitized data or a combination of both). Categories were aggregated to produce a set of integrated findings in the form of a set of recommendations or conclusions.

\section{Appraisal of level of evidence}

The level of evidence was assessed at the study level. The level of evidence for quantitative studies was assessed using the Grading of Recommendations Assessment, Development and Evaluation (GRADE) system, ${ }^{41}$ that ranks evidence as very low, low, 
moderate, and high. According to this approach, all randomized controlled trials start with a ranking of 'high' while all other study designs start with 'low'. This a-priori rank can then be adjusted (i.e., downgraded or upgraded) after considering eight assessment criteria and making a judgement about quality based on these.

The ConQual system was used to establish the confidence for qualitative evidence which included qualitative studies and integrated findings. ${ }^{42}$ According to the ConQual approach, all qualitative studies start with a ranking of 'high' on a scale of very low, low, moderate, and high. This ranking system then allows the findings of individual studies to be downgraded based on their dependability (i.e., appropriateness of the conduct of the research with research aims and purpose) and credibility (i.e., findings classified as unequivocal, credible, or unsupported). ${ }^{37}$ The integrated finding may then be downgraded based on the aggregate level of dependability from across the included findings. Downgrading for credibility may occur when not all the findings included in an integrated finding are considered unequivocal. ${ }^{42}$

Any disagreements during the selection process, quality assessment, data extraction, transformation, synthesis and integration, and appraisal of the level of evidence was resolved by involving a third reviewer.

\section{Results}

\section{Review process}

Of the 1722 articles identified, after duplicate removal $(n=298)$ and screening for title and abstract ( $n=1398), 26$ entered the full text review process. Fifteen articles were further excluded according to the above-mentioned criteria; no articles were included from the reference lists of selected papers. Finally, eight quantitative studies and three qualitative studies were included in the review (Figure $1)$.

Quality assessment is reported in Table 1 and Appendix 3.

\section{Characteristics of included studies}

The included studies were conducted in seven countries: two in the United Kingdom, ${ }^{43,44}$ two in the United States, ${ }^{45,} 46$ two in Canada,${ }^{38,} 47$ one in Australia, ${ }^{48}$ one in the Netherlands, ${ }^{49}$ and three were transnational studies..$^{50-52}$

All except two studies ${ }^{38,47}$ on the same cohort of patients were conducted after 2010.

Studies involved a median of twelve nursing homes, from one ${ }^{45,46}$ to $44^{43}$; only two studies reported the nursing home size which ranged from 40 to 99 beds. ${ }^{43}, 44$ Nursing homes had a main for- 
profit $^{43}$ or not for-profit ${ }^{38,47,50}$ profile. No information was provided about physician availability in the facilities.

The qualitative studies employed an ethnographic, ${ }^{44}$ qualitative descriptive, ${ }^{48}$ or longitudinal case study $^{46}$ methodology. The quantitative studies adopted randomized controlled ${ }^{38,45,47}$ and crosssectional $^{43,49-52}$ designs.

Qualitative data were collected from face-to-face semi-structured individual interviews with family caregivers $(n=2)^{38,44}$ and healthcare professionals $(n=2),{ }^{44,48}$ healthcare professionals' reflective diary $(\mathrm{n}=1),{ }^{44}$ and email letters $(\mathrm{n}=1) .{ }^{46}$ Quantitative data were collected from postal questionnaires $(\mathrm{n}=4),{ }^{49-52}$ family caregivers' structured face-to-face interviews with the questionnaire format $(\mathrm{n}=$ $3), 38,47,51$ telephone questionnaires $(n=1),{ }^{45}$ and online surveys $(n=1) .{ }^{43}$

Sample sizes ranged from one ${ }^{46}$ to $188^{50}$, with the qualitative studies having smaller samples. A total of 443 healthcare professionals, 437 family caregivers, and 49 nursing home directors are represented in the review findings.

Studies explored the views of family caregivers, ${ }^{38,45-47,51}$ healthcare professionals, ${ }^{50,52}$ and nursing home managers, ${ }^{43}$ with two studies ${ }^{48,49}$ including both family caregivers and healthcare professionals and one study ${ }^{44}$ family caregivers, healthcare professionals and nursing home managers (Table 1).

\section{Interventions to support family caregivers in included studies}

In all, seven unique interventions across 11 studies were identified. A booklet about comfort care in advanced dementia ${ }^{49-52}$ and a psychoeducational programme ${ }^{38,47}$ were evaluated in multiple studies. Interventions were gathered into three main categories including a) provision of information $(\mathrm{n}=5) ;{ }^{43}$, $49-52$ b) psychoeducational programmes $(n=2) ; 38,47$ and c) family meetings associated with written information, ${ }^{48}$ psychosocial support, ${ }^{45}$ education, ${ }^{44}$ or all these three aspects simultaneously ${ }^{46}$ (Table 2). Specifically, included studies explored practices adopted to inform family caregivers of people with dementia about end of life; ${ }^{43}$ acceptability and usefulness of written information alone ${ }^{49-52}$ or in association with family meetings ${ }^{48}$ to improve end-of-life discussions about dementia care; benefits of psychoeducational programmes for family caregivers' psychological health and competence in dealing with healthcare professionals; ${ }^{38,47}$ and benefits of family meetings associated with psychosocial support, ${ }^{45}$ educational programmes, ${ }^{44}$ or written information and education ${ }^{46}$ (Table 1).

\section{Data synthesis}

Of the 46 findings extracted, 23 were qualitative and 23 quantitative (Table 1, Table 3). All qualitative findings were rated as unequivocal and thus included in the synthesis in addition to the qualitized 
data. The level of credibility for each qualitative finding with participants' direct quotations is reported in Table 1.

Qualitative and qualitized data were assembled into seven categories, then combined in the following three integrated findings (Table 3, Figure 2):

Integrated finding 1. End-of-life dialogue should be ongoing and provide adequate time and space for sensitive discussion to establish a family caregivers-healthcare professionals partnership, promote shared decision-making and improve the quality of family caregivers' remaining time with their relative while offering emotional support

Twelve qualitative findings from four studies ${ }^{38,44,46,48}$ formed two categories which constituted the first integrated finding. This integrated finding revealed that end-of-life discussions should start as early as possible in the disease trajectory when the first cognitive problems arise and be ongoing: this provides family caregivers emotional support and enough time to process information, thus establishing a partnership between family caregivers and healthcare professionals and promoting shared decisions about end-of-life care.

Category 1: Ongoing discussion between healthcare professionals and family caregivers is pivotal to promote informed decisions, establish a partnership, provide emotional support and improve the relationship between family caregivers and their relative at the end of life

Ongoing dialogue helped building trusting relationships between family caregivers and healthcare professionals, provided reassurance, and allowed time for family caregivers to process information about their relative's health conditions. ${ }^{44,} 46$ Ongoing discussions appeared to increase family caregivers' awareness about their relative's worsening conditions and prognosis and increased their capacity to make informed decisions, ${ }^{44}, 46$ in addition to helping them feel less emotionally unsettled. ${ }^{46,48}$

Family caregivers usually desired to be engaged in discussions rather than 'being told' ${ }^{48}$ and when this happened they felt able to successfully express their dissatisfaction with their relative's care to the healthcare professionals and to collaborate together to find solutions. ${ }^{38}$ Moreover, family caregivers described the benefits of the dialogue process for the relationship with their relative, reporting better communication and more pleasant visits. ${ }^{38}$

Category 2: Consideration of the manner and location when discussing with family caregivers about their relative's end-of-life care preferences is important 
The physical environment where end-of-life discussions took place as well as how healthcare professionals sustained such discussions were key aspects. Communal areas such as a dining room or lounge were deemed unsuitable for sensitive discussions with family caregivers, and privacy and intimacy emerged as essential aspects to be considered. ${ }^{44}$ Moreover, great emphasis was put on the importance of providing information in a sensitive way, while addressing family caregivers' grief and guilt and their current issues and concerns before discussing future plans of care. ${ }^{44}$

\section{Integrated finding 2. End-of-life discussions should be face-to-face and guided by supporting written information whose provision may vary in timing and way according to family caregivers' preferences and the context}

Nineteen findings (17 qualitized and 2 qualitative) from eight studies $38,43,44,48-52$ formed two categories which constituted the second integrated finding. This integrated finding showed that endof-life discussions about dementia care with family caregivers should be face-to-face and supported by written information; the timing and way to provide written information may be influenced by family caregivers' preferences and the organizational policies and cultural context.

Category 3: End-of-life discussions should be face-to-face, structured around a set of pre-defined topics and supported by written information to educate and reassure family caregivers about care options at the end of life

Most nursing homes provided family caregivers face-to-face information and rates of discussing depended on the topic: $77.3 \%$ of discussions explored advance care planning about resident's wishes for the future care while only $38.6 \%$ focused on legal financial arrangements. ${ }^{43}$ Moreover, both healthcare professionals and family caregivers reported the need ${ }^{48,49}$ and value ${ }^{44}$ of providing written information about care options at the end of life for people with dementia to support discussion. All findings relating to written information to support face-to-face discussion highlighted the acceptability and usefulness of a booklet to provide information and reassure family caregivers about care options in advanced dementia at the end of life, according to both the healthcare professionals'49, 50,52 and family caregivers' perspective. ${ }^{49,51}$ Family caregivers reported that they gained confidence as decision makers and felt better able to engage in discussion when a discussion tool structured around a set of pre-defined topics was available. ${ }^{48}$ Witten information emerged as useful regardless of the organizational and cultural context. ${ }^{50}$

Category 4: Consideration of when to provide written information about care options at the end of life and how to make them available to family caregivers is essential 
Variability in the preferred timing of information provision about care options in advanced dementia emerged among healthcare professionals and family caregivers. ${ }^{49}$ However, preference of timing was highly variable also across individuals and countries. ${ }^{50,51}$ Most nurses indicated that the best moment to provide written information was when there are discussions about a medical problem for which comfort care is an option, however, the proportion of nurses who thought an informational booklet could be provided at the time of dementia diagnosis or before moving to a nursing home was higher in Japan and English Canada than in French Canada. ${ }^{50}$ The dying phase was the least preferred time among family caregivers, however, the proportion of Italian family caregivers who would have wanted to receive an informational booklet at the time of dementia diagnosis or shortly afterwards was higher than among Canadian and Dutch family caregivers. ${ }^{51}$

Both family caregivers and healthcare professionals agreed that the attending physician or nurse should have a role in providing written information. ${ }^{49,51}$

\section{Integrated finding 3. Family caregivers should be offered tailored psychoeducational} programmes and/or regular family meetings about dementia care at the end of life according to their specific information and emotional needs to promote understanding about their relative's health conditions, acceptance of the upcoming loss, and empowerment in facing challenging end-of-life-related issues

Fifteen findings ( 6 qualitized and 9 qualitative) from six studies ${ }^{38,43-47}$ formed three categories which constituted the third integrated finding. This integrated finding highlighted that psychoeducational programmes should be tailored to family caregivers' needs to empower them when confronted with end-of-life issues and promote their understanding about their relative's prognosis and proximity to dying.

Category 5: Psychoeducational programmes and/or regular family meetings are needed to effectively relieve family caregivers' strain while just one meeting or simply providing information is not enough; involvement of professionals experienced in psychological care may be required to help family caregivers manage their psychological distress and develop problem solving skills

Most nursing homes offered family meetings to support family caregivers, while only a few offered family education sessions. ${ }^{43}$ When family caregivers were involved in regular in-person meetings with a psychologist and provided with personalized information and advice in step with the evolution of the disease, they perceived education, counseling and psychosocial support, thus flourishing and feeling happy with themselves most of the time, while deepening their relationship with and becoming an advocate for their relative. ${ }^{46}$ Also, psychoeducational programmes structured 


\section{Category 6: Interaction with peers and healthcare professionals independent from the staff of the} nursing home is useful to bring out family caregivers' needs of education and can be a source of emotional support

Two qualitative findings from one study ${ }^{44}$ contributed to this category. Eliciting family caregivers' needs for dementia education may be challenging. Strategies such as interacting with other family caregivers in structured family sessions and with healthcare professionals or teams independent from the nursing home eased talking and generating questions about dementia and its progression, as well as provided an alternative view of the residents' needs and how to improve their care. ${ }^{44}$

Category 7: Family caregivers should be helped to take care of themselves by promoting reflection, reframing, acceptance, and finally empowerment

Family caregivers reported that educational programmes helped them to take care of themselves, they learned to dedicate more time to themselves without feeling guilt. ${ }^{38}$ According to family caregivers' perspective, educational programmes worked at two levels by 1) promoting the development of coping strategies such as reflection, reframing and acceptance of unchangeable negative events such as their relative's loss to counteract stressors, ${ }^{38,46}$ and 2) by making them aware of their strengths. ${ }^{38}$ Educational programmes allowed family caregivers to stop, step back from their current situation, take time to think and change their way of looking at things. ${ }^{38,46}$ The more family caregivers understood including the fact that they could not fix some things ${ }^{46}$ and not to accept what could not be changed was just not healthy or helpful in any way to anyone, ${ }^{38}$ the less anxious and the 
more empathetic they felt. Moreover, educational programmes seemed to help family caregivers to exercise control through an increased belief in their potential. ${ }^{38}$

\section{Level of evidence}

Among quantitative evidence $(n=8)$, three studies received a ranking of low, ${ }^{43,49,50}$ three studies of moderate, ${ }^{38,45,47}$ and two studies of high ${ }^{51,52}$ (Table 1). Main reasons to downgrade and upgrade the a-priori ranking of quality were the risk of bias and large magnitude of effect, respectively (Appendix 4a).

Two qualitative studies ${ }^{44}, 46$ were ranked as providing high evidence and one study ${ }^{48}$ received moderate evidence due to the downgrading of the dependability criterion by one level (Table 1 , Appendix 4b).

The quality of evidence for the three synthesized findings received moderate ranking due to the downgrading of the dependability criterion by one level (Table 3, Appendix 4c).

\section{Discussion}

The purpose of this Mixed-Methods Systematic Review was to gather and synthesize knowledge about interventions employed to support family caregivers of people with advanced dementia at the end of life in nursing homes in the form of recommendations for daily practice. We found that the evidence which sustains recommendations was of moderate quality and comprehensively advises (i) ongoing dialogue between healthcare professionals and family caregivers and adequate time and space for sensitive discussions, (ii) face-to-face discussions supported by written information whose timing of supply may vary according to family caregivers' preferences and the organizational policies and cultural context; and (iii) structured psychoeducational programmes and/or regular family meetings about dementia care at the end of life tailored to family caregivers' specific needs. Overall, the small number of included empirical studies suggests large room of improvement for evidencebased interventions to support family caregivers of people with advanced dementia at the end of life living in a nursing home. Moreover, studies were mostly concentrated in the last decade, suggesting increasing attention to the need to educate and reassure family caregivers about care options for their relative with advanced dementia at the end of life, despite facilities differing in organizational policies and cultural context.

\section{Recommendation 1}

A regular open dialogue is essential to facilitate partnerships between family caregivers and healthcare professionals and promote both the provision of preference-based care and family empowerment. ${ }^{38,44,46,48}$ Moreover, quality communication provides emotional support to family 
caregivers, builds trusting relationships and informs good decision-making processes. ${ }^{53}$, 54 When family caregivers trust healthcare professionals, they are usually satisfied with their decision-making experience and the care provided aligns with family caregivers' and residents' wishes. ${ }^{55}$ Instead, when a sense of belonging and attachment lacks, family caregivers experience detachment and isolation. ${ }^{56}$ Good relationships with the nursing home staff is a source of emotional support for family caregivers ${ }^{57}$ and essential to provide good quality end-of-life care. ${ }^{54}$

Establishing a dedicated space for sensitive end-of-life communication can provide family caregivers both privacy and proximity at end of life. ${ }^{58}$ Environmental design which improves social interaction and a home-like atmosphere has been found to positively impact end-of-life care. 58,59 However, even when attention is paid to the environment, end-of-life communication remains emotionally challenging for both healthcare professionals and family caregivers. ${ }^{57,} 60$ Family caregivers usually expect that healthcare professionals start communication about end-of-life care, ${ }^{60}$ while healthcare professionals may struggle to initiate and sustain such sensitive discussions. ${ }^{61}$ Therefore, it is important that healthcare professionals support each other ${ }^{62}$ to engage family caregivers in decision making which may reduce the uncertainty of choices taken at times of crisis and promote palliative-oriented care. ${ }^{63} \mathrm{How} /$ when to engage family caregivers is highly variable and requires a personalized approach, as discussed below in Recommendation 2.

\section{Recommendation 2}

The Covid-19 pandemic has further challenged end-of-life communication due to visiting restrictions which prevented family caregivers' in-person presence. ${ }^{64,65}$ However, also during pandemic times, family caregivers need to be involved in the decision making process, in a timely manner, to provide care consistent with their relative' wishes $^{66}$ and avoid their caregiving role to be disrupted with negative impact on their psychosocial and emotional well-being. ${ }^{67}$ This has forced a change in the way of communication between family caregivers and healthcare professionals by necessitating the use of remote Information and Communication Technologies. ${ }^{68,} 69$ Worthy examples of remote communication in the nursing home setting showed that bereaved family caregivers who reported effective remote communication with healthcare professionals had a better overall experience of endof-life care. ${ }^{68}$ This suggests that despite in-person discussions remain the first choice for end-of-life communication, Information and Communication Technologies-based discussions may be a valuable alternative when family caregivers' presence in nursing homes is not possible (e.g., visitation restrictions, long distance family caregivers).

Complementing end-of-life communication with written information may facilitate shared decision-making and help family caregivers to make an informed choice about their relative's endof-life care. ${ }^{43,} 44,48-52$ Written information promotes family caregivers' understanding of disease 
progression, prognosis and care options, while providing family caregivers the opportunity to go through information several times and process information at their own pace. ${ }^{70,71}$ In addition, written information may help healthcare professionals to introduce the issue of end-of-life care and guide family caregivers to reflect on their relative's values and preferences for future care. ${ }^{72}$ This suggests that end-of-life communication may be supported through a hybrid model of face-to-face communication, either in-person or using Information and Communication Technologies, complemented by written materials. A transnational ongoing study, known as mySupport, that involves a consortium of six countries is exploring the benefits of structured in-person or Information and Communication Technologies-based family care conferences associated with written information, as perceived by family caregivers of residents with advanced dementia and healthcare professionals. ${ }^{73}$ This study will inform about the feasibility to implement such a structured hybrid educational intervention and its impact on family caregivers and nursing home staff.

Consistent with previous authors, ${ }^{60,70}$ our findings suggest a great variability in the preferred timing of information despite the dying phase was the least preferred and most family caregivers desired discussions when medical problems arise or at the time of admission to a nursing home. ${ }^{49-51}$ Similarly, the responsibility for end-of-life discussions appears to vary across care settings, professional scope of practice and countries, and has been described as a 'hot potato', ${ }^{74}$ whereby everyone and no one is taking ownership. Our review confirms Dixon and Knapp's suggestion that the optimum approach both from an economic and quality effectiveness standpoint is a multi-disciplinary one. ${ }^{75}$ When a team-based approach is employed, family caregivers report higher quality communication and feel more involved in care planning that allows for a better-perceived death for their relative. ${ }^{76}$ Therefore, it is the role of all healthcare professionals to create an environment of openness so that patients and their family caregivers feel comfortable to voice their concerns regarding end-of-life issues and can be involved in planning end-of-life care.

\section{Recommendation 3}

Consistently with previous literature, ${ }^{77}$ our findings advocate that healthcare professionals should support family caregivers-centred care at the end of life through the provision of targeted information and socio-emotional care. Family caregivers of people with advanced dementia have unique diseasespecific information and support needs ${ }^{78}$ and experience significant stress during the transition from curative-oriented to palliative-oriented care. ${ }^{79}, 80$ Therefore, educational interventions should be preceded by in-depth assessment of family caregivers' positionality ${ }^{81}$ and incorporate strategies to promote their wellbeing during this transitioning period and beyond, in addition to providing tailored education. 
Our review suggests that psychoeducational programmes, which involve weekly small groups of family caregivers for up to 10 weeks, reduce their role overload and caregiving-related stress, and improve use of reframing and competence in dealing with healthcare professionals despite not significantly affecting psychological distress. ${ }^{38,47}$ Moreover, we found that just one family meeting with palliative care physicians or social workers does not improve family caregivers' depressive symptoms and life satisfaction. ${ }^{45}$ Instead, when family caregivers are involved in regular meetings with a psychologist and receive personalized information and advice as the disease evolves, they are more aware about their relative's disease trajectory, perceive better relationships with healthcare professionals and are more engaged in a shared decision-making process at the end of life. ${ }^{46}$ Also, regular meetings with healthcare professionals having a social science background and experienced in working with people with dementia increased family caregivers' perceived capacity to make informed decisions and provided reassurance. ${ }^{44}$ Thus, our findings highlight that psychoeducational programmes and regular meetings with healthcare professionals experienced in dementia care tailored to family caregivers' specific and changing emotional and information needs can promote self-care and empowerment. This is noteworthy since empowered family caregivers are more prone to understanding the nature of dementia and being engaged in shared decisions, and feel more prepared to advocate for their relative's dignity. ${ }^{82-85}$

This review also suggests that family sessions may be an important means for education and emotional support. ${ }^{43}, 44$ A study involving family caregivers of community dwelling people with dementia showed that the majority of their unmet needs related to their mental health and caregiver support groups ${ }^{86}$ Similarly, findings from an European cross-country evaluation of a meeting centers support programme highlighted that peer support can help to increase the capacity to deal with the challenges caused by dementia and can promote emotional balance. ${ }^{87}$ Those family caregivers who were most satisfied with the discussion groups offered in such programme, had experienced strong emotional support. ${ }^{87}$ It may be postulated that family caregivers find comfort and support with each other in sharing and discussing matters related to the emotional impact of dementia. Structured family sessions facilitated by professionals experienced in psychological care may thus be a promising avenue to be considered when planning interventions to support family caregivers of nursing home residents with advanced dementia. In the community setting, professionally facilitated peer support has already shown positive effects on mental health outcomes of family caregivers of people with dementia. ${ }^{88}$

\section{Strengths and weaknesses}


This study provides a set of recommendations about interventions to support family caregivers of people with advanced dementia at the end of life in nursing homes by synthetizing the relevant qualitative and quantitative literature of interventions delivered at the caregiver level. A strength of this study is the convergent integrated approach ${ }^{28}$ which minimizes methodological differences between qualitative and quantitative studies and allows to present results together because both are viewed as addressing the same research question. Our recommendations are limited by not considering organizational and policy level interventions and may suffer from bounded transferability to Eastern cultures since they are mainly based on studies conducted in Western countries. Moreover, the limited available literature prevented from making recommendations more actionable. Further methodologically sound studies are needed to clearly point out which, how, when and by whom interventions to support family caregivers of people with advanced dementia at the end of life in nursing home should be delivered to maximize their effectiveness.

\section{Conclusions}

Despite interventions that may benefit family caregivers of people with advanced dementia at the end of life in nursing home and where, how, when and by whom they should be provided is a topic which has been gaining increasing interest in the recent years, available evidence is still limited.

Our findings are supported by evidence of moderate quality and advise healthcare professionals to establish ongoing and sensitive discussion with family caregivers to promote partnership, informed and shared decisions around their relative's end-of-life care and provide emotional support. Discussions should be face-to-face, structured around a set of pre-defined topics and supported by written information to reinforce messages. Discussions should take place in a private environment avoiding communal areas and preference of timing may be variable across individuals and contexts.

This review also suggests that family caregivers may benefit from structured psychoeducational programmes and/or regular family meetings tailored to their specific information and emotional needs to promote understanding about their relative's prognosis, acceptance of the approaching death, and enhance belief in their inner strengths and potential. Interacting with peers and healthcare professionals independent from the nursing home or experienced in psychological care may help family caregivers to identify their dementia education needs, manage distress and develop problem solving skills.

Future research should explore the potential benefit of structured hybrid psychoeducational interventions which complement face-to-face discussion with written materials as well as professionally facilitated peer support to promote the psychosocial and emotional well-being of family caregivers of people with advanced dementia at the end of life. 


\section{Acknowledgements}

The Authors would thank Dr Barbara Martin for her support in retrieving the full text of articles assessed for inclusion and mySupport study team for facilitating this review.

\section{Declaration of conflicting interests}

The author(s) declared no potential conflicts of interest with respect to the research, authorship, and/or publication of this article.

\section{Funding}

This study has received funding from the European Union's Horizon 2020 research and innovation programme under grant agreement No 643417.

This is an EU Joint Programme - Neurodegenerative Disease Research (JPND) project. The project is supported through the following funding organisations under the aegis of JPND - www.jpnd.eu: Canada, Canadian Institutes of Health Research; Czech Republic, Ministry of Education, Youth and Sport; Netherlands, Netherlands Organisation for Health Research and Development; Republic of Ireland, Health Research Board; UK, Alzheimer's Society.

\section{Supplemental material}

Supplemental material for this article is available online.

\section{References}

1. Prince M, Bryce R, Albanese E, et al. The global prevalence of dementia: A systematic review and metaanalysis. Alzheimer's \& dementia 2013; 9: 63-75. e62.

2. World Health Organization. Dementia; 2020. Available from https://www.who.int/newsroom/fact-sheets/detail/dementia. Last access on May $3^{\text {rd }} 2021$.

3. Prince M WA, Guerchet M, Ali G-C, et al. World Alzheimer Report 2015 - The global impact of dementia. An analysis of prevalence, incidence, cost and trends. London: Alzheimer's Disease International; 2015. Available from https://www.alzint.org/resource/world-alzheimrreport-2015/

4. Lord K, Livingston G, Robertson S, et al. How people with dementia and their families decide about moving to a care home and support their needs: Development of a decision aid, a qualitative study. BMC Geriatr 2016; 16: 68. 
5. Birkenhäger-Gillesse EG, Kollen BJ, Zuidema SU, et al. The "more at home with dementia" program: A randomized controlled study protocol to determine how caregiver training affects the well-being of patients and caregivers. BMC Geriatr 2018; 18: 252.

6. Mittelman MS, Haley WE, Clay OJ, et al. Improving caregiver well-being delays nursing home placement of patients with alzheimer disease. Neurology 2006; 67: 1592-1599.

7. Sanford AM, Orrell M, Tolson D, et al. An international definition for "nursing home". J Am Med Dir Assoc 2015; 16: 181-184.

8. Alzheimer's Association. 2017 Alzheimer's disease facts and figures. Alzheimer's \& Dementia 2017; 13: 325-373.

9. Peacock SC, Hammond-Collins K, Forbes DA. The journey with dementia from the perspective of bereaved family caregivers: A qualitative descriptive study. BMC Nurs 2014; 13: 42 .

10. Abreu W, Tolson D, Jackson GA, et al. A cross-sectional study of family caregiver burden and psychological distress linked to frailty and functional dependency of a relative with advanced dementia. Dementia (London) 2020; 19: 301-318.

11. Brodaty H, Donkin M. Family caregivers of people with dementia. Dialogues Clin Neurosci 2009; 11: 217-228.

12. Gaugler JE, Mittelman MS, Hepburn K, et al. Clinically significant changes in burden and depression among dementia caregivers following nursing home admission. BMC Med 2010; 8: 1-14.

13. Schulz R, Belle SH, Czaja SJ, et al. Long-term care placement of dementia patients and caregiver health and well-being. JAMA 2004; 292: 961-967.

14. Tornatore JB, Grant LA. Burden among family caregivers of persons with Alzheimer's disease in nursing homes. Gerontologist 2002; 42: 497-506.

15. Vick JB, Ornstein KA, Szanton SL, et al. Does caregiving strain increase as patients with and without dementia approach the end of life? J Pain Symptom Manage 2019; 57: 199-208. e2.

16. Caron CD, Griffith J, Arcand M. End-of-life decision making in dementia: The perspective of family caregivers. Dementia 2005; 4: 113-136.

17. Petriwskyj A, Gibson A, Parker D, et al. A qualitative metasynthesis: Family involvement in decision making for people with dementia in residential aged care. Int J Evid Based Healthc 2014; 12: 87-104.

18. Committee on Family Caregiving for Older Adults; Board on Health Care Services; Health and Medicine Division; National Academies of Sciences, Engineering, and Medicine; Schulz R, Eden J, editors. Families caring for an aging America. Washington (DC): National 
Academies

Press

(US);

2016.

Available

from:

https://www.ncbi.nlm.nih.gov/books/NBK396401/

19. Gaugler JE. Family involvement in residential long-term care: A synthesis and critical review. Aging Ment Health 2005; 9: 105-118.

20. Givens JL, Prigerson HG, Kiely DK, et al. Grief among family members of nursing home residents with advanced dementia. Am J Geriatr Psychiatry 2011; 19: 543-550.

21. Chan D, Livingston G, Jones L, et al. Grief reactions in dementia carers: A systematic review. Int J Geriatr Psychiatry 2013; 28: 1-17.

22. Fosse A, Schaufel MA, Ruths S, et al. End-of-life expectations and experiences among nursing home patients and their relatives--a synthesis of qualitative studies. Patient Educ Couns 2014; 97: 3-9.

23. van der Steen JT, Radbruch L, Hertogh CM, et al. White paper defining optimal palliative care in older people with dementia: A delphi study and recommendations from the European Association for Palliative Care. Palliat Med 2014; 28: 197-209.

24. Romero MM, Ott CH, Kelber ST. Predictors of grief in bereaved family caregivers of person's with Alzheimer's disease: A prospective study. Death Stud 2014; 38: 395-403.

25. Frias CE, Garcia-Pascual M, Montoro M, et al. Effectiveness of a psychoeducational intervention for caregivers of people with dementia with regard to burden, anxiety and depression: A systematic review. J Adv Nurs 2020; 76: 787-802.

26. Brooks D, Fielding E, Beattie E, et al. Effectiveness of psychosocial interventions on the psychological health and emotional well-being of family carers of people with dementia following residential care placement: A systematic review. JBI Database System Rev Implement Rep 2018; 16: 1240-1268.

27. Müller C, Lautenschläger S, Meyer G, et al. Interventions to support people with dementia and their caregivers during the transition from home care to nursing home care: A systematic review. Int J Nurs Stud 2017; 71: 139-152.

28. Lizarondo L, Stern C, Carrier J, et al. Chapter 8: Mixed methods systematic reviews. In: Aromataris E, Munn Z (Editors). JBI manual for evidence synthesis. JBI, 2020. Available from https://synthesismanual.jbi.global.

29. Campbell M, McKenzie JE, Sowden A, et al. Synthesis without meta-analysis (SWIM) in systematic reviews: Reporting guideline. BMJ 2020; 368.

30. Moher D, Liberati A, Tetzlaff J, et al. Preferred reporting items for systematic reviews and meta-analyses: The Prisma statement. J Clin Epidemiol 2009; 62: 1006-1012. 
31. Hui D, Nooruddin Z, Didwaniya N, et al. Concepts and definitions for "actively dying," "end of life," "terminally ill," "terminal care," and "transition of care": a systematic review. J Pain Symptom Manage 2014; 47: 77-89.

32. Broady TR, Saich F, Hinton T. Caring for a family member or friend with dementia at the end of life: A scoping review and implications for palliative care practice. Palliat Med 2018; 32: 643-656.

33. Munn Z, Moola S, Lisy K, et al. Methodological guidance for systematic reviews of observational epidemiological studies reporting prevalence and cumulative incidence data. Int J Evid Based Healthc 2015; 13: 147-153.

34. Tufanaru C, Munn Z, Aromataris E, et al. Chapter 3: Systematic reviews of effectiveness. In: Aromataris E, Munn Z (Editors). JBI Manual for Evidence Synthesis. JBI, 2020. Available from https://synthesismanual.jbi.global.

35. Lockwood C, Munn Z, Porritt K. Qualitative research synthesis: Methodological guidance for systematic reviewers utilizing meta-aggregation. Int J Evid Based Healthc 2015; 13: 179-187.

36. Moola S, Munn Z, Tufanaru C, et al. Chapter 7: Systematic reviews of etiology and risk. In: Aromataris E, Munn Z (Editors). JBI Manual for Evidence Synthesis. JBI, 2020. Available from https://synthesismanual.jbi.global.

37. Joanna Brrigs Institute. Reviewers' manual. 2014. Available from http://joannabriggs.org/assets/docs/sumari/ReviewersManual-2014.pdf

38. Ducharme F, Levesque L, Lachance L, et al. 'Taking care of myself' efficacy of an intervention programme for caregivers of a relative with dementia living in a long-term care setting. Dementia 2005; 4: 23-47.

39. Sandelowski M, Voils CI, Barroso J. Defining and designing mixed research synthesis studies. Res Sch 2006; 13: 29.

40. Hong QN, Pluye P, Bujold M, et al. Convergent and sequential synthesis designs: Implications for conducting and reporting systematic reviews of qualitative and quantitative evidence. Syst Rev 2017; 6: 61.

41. Ryan R, Hill S. How to GRADE the quality of the evidence. Cochrane Consumers and Communication Group, 2016. Available at http://cccrg.cochrane.org/author-resources. Version 3.0 December 2016.

42. Munn Z, Porritt K, Lockwood C, et al. Establishing confidence in the output of qualitative research synthesis: the ConQual approach. BMC Med Res Methodol 2014; 14: 108. 
43. Moore KJ, Crawley S, Cooper C, et al. How do admiral nurses and care home staff help people living with dementia and their family carers prepare for end-of-life? Int J Geriatr Psychiatry 2020; 35: 405-413.

44. Saini G, Sampson EL, Davis S, et al. An ethnographic study of strategies to support discussions with family members on end-of-life care for people with advanced dementia in nursing homes. BMC Palliat Care 2016; 15: 55.

45. Reinhardt JP, Chichin E, Posner L, et al. Vital conversations with family in the nursing home: Preparation for end-stage dementia care. J Soc Work End Life Palliat Care 2014; 10: 112126.

46. Sabat SR. Flourishing of the self while caregiving for a person with dementia: A case study of education, counseling, and psychosocial support via email. Dementia 2011; 10: 81-97.

47. van der Steen JT, de Graas T, Arcand M, et al. Een handreiking voor familieleden over palliatieve zorg bij dementie [Evaluation of a family booklet on comfort care in dementia by professional and family caregivers]. Tijdschr Gerontol Geriatr 2011; 42: 215-225.

48. van der Steen JT, Toscani F, de Graas T, et al. Physicians' and nurses' perceived usefulness and acceptability of a family information booklet about comfort care in advanced dementia. $J$ Palliat Med 2011; 14: 614-622.

49. Ducharme F, Lévesque L, Giroux F, et al. Follow-up of an intervention program for caregivers of a relative with dementia living in a long-term care setting: Are there any persistent and delayed effects? Aging Ment Health 2005; 9: 461-469.

50. Stirling C, McLnerney F, Andrews S, et al. A tool to aid talking about dementia and dying-development and evaluation. Collegian 2014; 21: 337-343.

51. Arcand M, Brazil K, Nakanishi M, et al. Educating families about end-of-life care in advanced dementia: Acceptability of a canadian family booklet to nurses from Canada, France, and Japan. Int J Palliat Nurs 2013; 19: 67-74.

52. van der Steen JT, Arcand M, Toscani F, et al. A family booklet about comfort care in advanced dementia: Three-country evaluation. J Am Med Dir Assoc 2012; 13: 368-375.

53. Bauer M, Fetherstonhaugh D, Lewis V. Attitudes towards family-staff relationships in Australian residential aged care settings: Development and psychometric evaluation of the 'family and staff relationship attitude tool' (FASRAT). Australas J Ageing 2014; 33: 170-173.

54. Gonella S, Basso I, De Marinis MG, et al. Good end-of-life care in nursing home according to the family carers' perspective: A systematic review of qualitative findings. Palliat Med 2019; 33: 589-606. 
55. Rosemond C, Hanson LC, Zimmerman S. Goals of care or goals of trust? How family members perceive goals for dying nursing home residents. J Palliat Med 2017; 20: 360-365.

56. Lopez RP, Mazor KM, Mitchell SL, et al. What is family-centered care for nursing home residents with advanced dementia? Am J Alzheimers Dis Other Demen 2013; 28: 763-768.

57. Groebe B, Rietz C, Voltz R, et al. How to talk about attitudes toward the end of life: A qualitative study. Am J Hosp Palliat Care 2019; 36: 697-704.

58. Sagha Zadeh R, Eshelman P, Setla J, et al. Environmental design for end-of-life care: An integrative review on improving the quality of life and managing symptoms for patients in institutional settings. J Pain Symptom Manage 2018; 55: 1018-1034.

59. van der Steen JT, Lemos Dekker N, Gijsberts MHE, et al. Palliative care for people with dementia in the terminal phase: A mixed-methods qualitative study to inform service development. BMC Palliat Care 2017; 16: 28.

60. Gjerberg E, Lillemoen L, Førde R, et al. End-of-life care communications and shared decision-making in norwegian nursing homes--experiences and perspectives of patients and relatives. BMC Geriatr 2015; 15: 103.

61. Schonfeld TL, Stevens EA, Lampman MA, et al. Assessing challenges in end-of-life conversations with elderly patients with multiple morbidities. Am J Hosp Palliat Care 2012; 29: $260-267$.

62. Bamford C, Lee R, McLellan E, et al. What enables good end of life care for people with dementia? A multi-method qualitative study with key stakeholders. BMC Geriatr 2018; 18 : 302.

63. Gonella S, Campagna S, Basso I, et al. Mechanisms by which end-of-life communication influences palliative-oriented care in nursing homes: A scoping review. Patient Educ Couns 2019; 102: 2134-2144.

64. Chen AT, Ryskina KL, Jung HY. Long-term care, residential facilities, and Covid-19: An overview of federal and state policy responses. J Am Med Dir Assoc 2020; 21: 1186-1190.

65. Miralles O, Sanchez-Rodriguez D, Marco E, et al. Unmet needs, health policies, and actions during the Covid-19 pandemic: A report from six european countries. Eur Geriatr Med 2021; 12: $193-204$.

66. Bolt SR, van der Steen JT, Mujezinović I, et al. Practical nursing recommendations for palliative care for people with dementia living in long-term care facilities during the Covid19 pandemic: A rapid scoping review. Int J Nurs Stud 2021; 113: 103781. 
67. O'Caoimh R, O'Donovan MR, Monahan MP, et al. Psychosocial impact of Covid-19 nursing home restrictions on visitors of residents with cognitive impairment: A cross-sectional study as part of the engaging remotely in care (ERIC) project. Front Psychiatry 2020; 11: 585373.

68. Ersek M, Smith D, Griffin H, et al. End-of-life care in the time of Covid-19: Communication matters more than ever. J Pain Symptom Manage 2021.

69. Feder S, Smith D, Griffin H, et al. "Why couldn't I go in to see him?" Bereaved families' perceptions of end-of-life communication during Covid-19. J Am Geriatr Soc 2021; 69: $587-$ 592.

70. Chang E, Easterbrook S, Hancock K, et al. Evaluation of an information booklet for caregivers of people with dementia: An Australian perspective. Nurs Health Sci 2010; 12: 45-51.

71. Sussman T, Kaasalainen S, Lee E, et al. Condition-specific pamphlets to improve end-of-life communication in long-term care: Staff perceptions on usability and use. J Am Med Dir Assoc 2019; 20: 262-267.

72. Sussman T, Kaasalainen S, Mintzberg S, et al. Broadening end-of-life comfort to improve palliative care practices in long term care. Can J Aging 2017; 36: 306-317.

73. mySupport study. Scaling up the family carer decision support intervention: A transnational effectiveness-implementation evaluation. 2019-2022. Access at https://mysupportstudy.eu

74. Harrison Dening K. Advance care planning in dementia [Internet]. Dublin: All Ireland Institute of Hospice and Palliative Care; 2016 July 18. Video: 39.54 min. Available from http://www.professionalpalliativehub.com/resource-centre/palliative-careneurodegeneration-advance-care-planning-dementia

75. Dixon J, Knapp M. Whose job? The staffing of advance care planning support in twelve international healthcare organizations: A qualitative interview study. BMC Palliat Care 2018; 17: 78.

76. Frey R, Barham S, Balmer D, et al. Palliative care delivery in residential aged care: Bereaved family member experiences of the supportive hospice aged residential exchange (SHARE) intervention. BMC Palliat Care 2020; 19: 127.

77. Whitlatch CJ, Orsulic-Jeras S. Meeting the informational, educational, and psychosocial support needs of persons living with dementia and their family caregivers. Gerontologist 2018; 58: S58-s73.

78. Thompson G, Hack T, Rodger K, et al. Clarifying the information and support needs of family caregivers of nursing home residents with advancing dementia. Dementia (London) 2020: 1471301220927617. 
79. Bijnsdorp FM, Pasman HRW, Boot CRL, et al. Profiles of family caregivers of patients at the end of life at home: A Q-methodological study into family caregiver' support needs. BMC Palliat Care 2020; 19: 51.

80. Oliveira D, Zarit SH, Orrell M. Health-promoting self-care in family caregivers of people with dementia: The views of multiple stakeholders. Gerontologist 2019; 59: e501-e511.

81. Elliott J, McNeil H, Ashbourne J, et al. Engaging older adults in health care decision-making: A realist synthesis. Patient 2016; 9: 383-393.

82. Boots LM, Wolfs CA, Verhey FR, et al. Qualitative study on needs and wishes of early-stage dementia caregivers: The paradox between needing and accepting help. Int Psychogeriatr 2015; 27: 927-936.

83. Jennings LA, Palimaru A, Corona MG, et al. Patient and caregiver goals for dementia care. Qual Life Res 2017; 26: 685-693.

84. Lindeza P, Rodrigues M, Costa J, et al. Impact of dementia on informal care: A systematic review of family caregivers' perceptions. BMJ Support Palliat Care 2020.

85. Poole M, Bamford C, McLellan E, et al. End-of-life care: A qualitative study comparing the views of people with dementia and family carers. Palliat Med 2018; 32: 631-642.

86. Zwingmann I, Michalowsky B, Esser A, et al. Identifying unmet needs of family dementia caregivers: Results of the baseline assessment of a cluster-randomized controlled intervention trial. J Alzheimers Dis 2019; 67: 527-539.

87. Szcześniak D, Rymaszewska J, Saibene FL, et al. Meeting centres support programme highly appreciated by people with dementia and carers: A European cross-country evaluation. Aging Ment Health 2021; 25: 149-159.

88. Han J, Guo G, Hong L. Impact of professionally facilitated peer support for family carers of people with dementia in a wechat virtual community. J Telemed Telecare 2020. doi: 10.1177/1357633X20910830. [Online ahead of print]. 
Figure 1. PRISMA flow-chart depicting the main stages of the systematic review process.

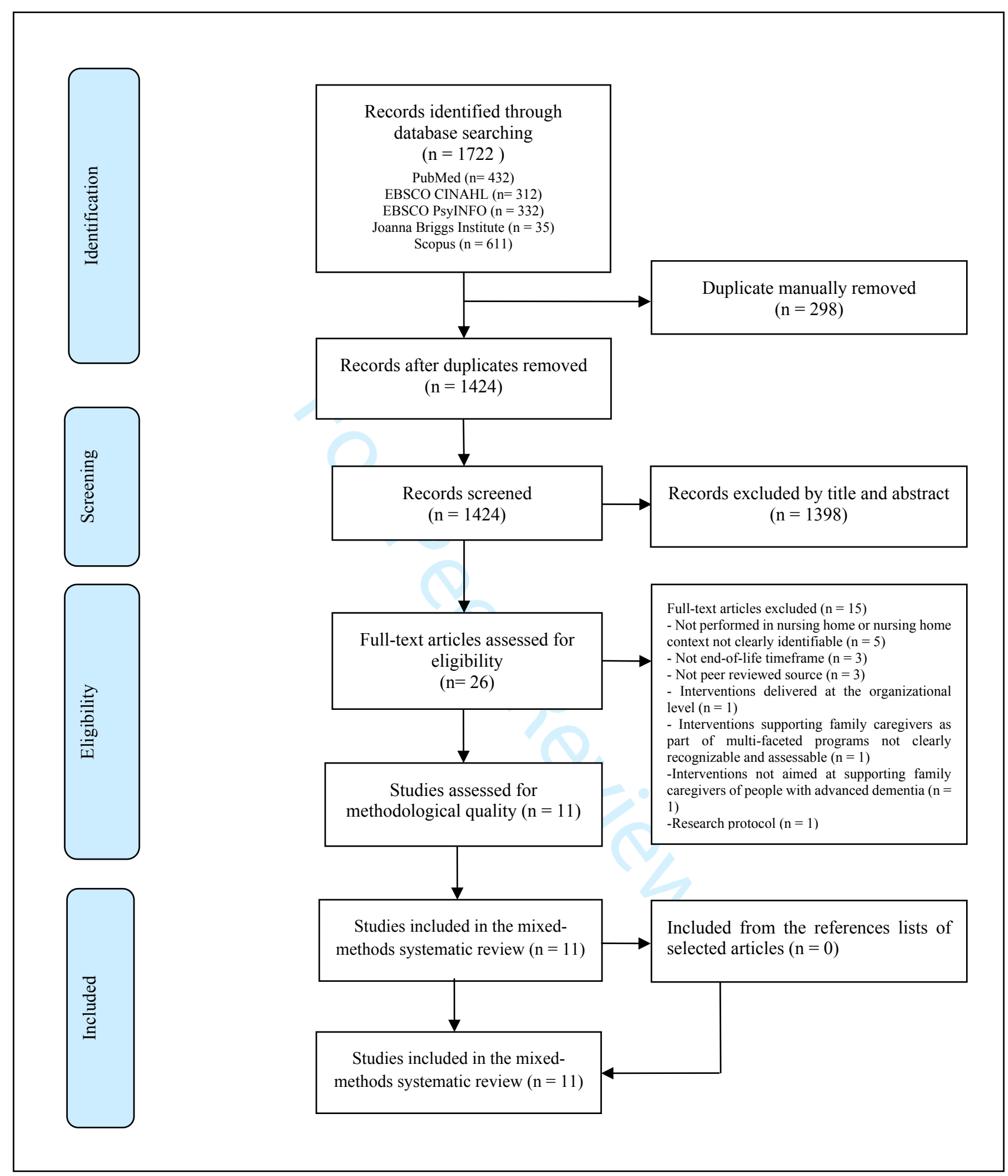


Figure 2. Categories and integrated findings.

Ongoing discussion between healthcare professionals and family caregivers is pivotal to promote informed decisions, establish a partnership, provide emotional support and improve the relationship between family caregivers and their relative at the end of life

Consideration of the manner and location when discussing with family caregivers about their relative's end-of-life care preferences is important

End-of-life discussions should be face-to-face, structured around a set of pre-defined topics and supported by written information to educate and reassure family caregivers about care options at the end of life

Consideration of when to provide written information about care options at the end of life and how to make them available to family caregivers is essential

Psychoeducational programmes and/or regular family meetings are needed to effectively relieve family caregivers' strain while just one meeting or simply providing information is not enough; involvement of professionals experienced in psychological care may be required to help family caregivers manage their psychological distress and develop problem solving skills

Interaction with peers and healthcare professionals independent from the staff of the nursing home is useful to bring out family caregivers' needs of education and can be a source of emotional support

Family caregivers should be helped to take care of themselves by promoting reflection, reframing, acceptance, and finally empowerment
End-of-life dialogue should be ongoing and provide adequate time and space for sensitive discussion to establish a family caregivershealthcare professionals partnership, promote shared decisionmaking and improve the quality of family caregivers' remaining time with their relative while offering emotional support

End-of-life discussions should be face-to-face and guided by supporting written information whose provision may vary in timing and way according to family caregivers' preferences and the context

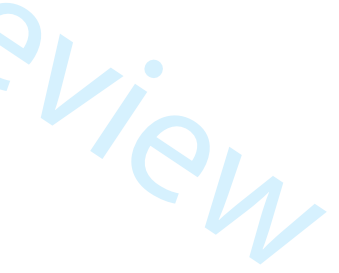

Family caregivers should be offered tailored psychoeducational programmes and/or regular family meetings about dementia care at the end of life according to their specific information and emotional needs to promote understanding about their relative's health conditions, acceptance of the upcoming loss, and empowerment in facing challenging end-of-life-related issues 
Table 1: Characteristics of the included studies

\begin{tabular}{|c|c|c|c|c|c|c|c|c|c|c|}
\hline $\begin{array}{l}\text { Author(s), } \\
\text { year (code) }\end{array}$ & $\begin{array}{l}\text { Type of } \\
\text { study }\end{array}$ & Methodology & $\begin{array}{l}\text { Geographical } \\
\text { context/ } \\
\text { characteristics } \\
\text { of } \mathrm{NH}\end{array}$ & $\begin{array}{l}\text { Participants } \\
\text { (number and } \\
\text { characteristics) }\end{array}$ & $\begin{array}{l}\text { Phenomena of } \\
\text { interest }\end{array}$ & Data collection & $\begin{array}{l}\text { Data } \\
\text { analysis }\end{array}$ & Findings & $\begin{array}{l}\text { Methodological } \\
\text { quality } \\
\text { appraisal }\end{array}$ & $\begin{array}{l}\text { Level of } \\
\text { evidence }\end{array}$ \\
\hline $\begin{array}{l}\text { Arcand et } \\
\text { al., } 2013 \\
\text { (H) }\end{array}$ & Quantitative & $\begin{array}{l}\text { Cross- } \\
\text { sectional }\end{array}$ & $\begin{array}{l}\mathrm{n}=2) \text {, French } \\
\text { Canada } \\
\text { English } \\
\text { Canada }(\mathrm{n}=3), \\
\text { France }(\mathrm{n}=4), \\
\text { Japan }(\mathrm{n}=3) / \\
\text { all non-for- } \\
\text { profit NHs; } \\
\text { Catholic } \\
\text { affiliation for } \\
\text { one NH }\end{array}$ & $\begin{array}{l}188 \text { nurses } \\
\text { Gender }= \\
\text { female } 156 \\
(83 \%) \\
\text { Age }=36.8- \\
49.1(10.8- \\
12.7)\end{array}$ & $\begin{array}{l}\text { Nurses' } \\
\text { perception of } \\
\text { acceptability and } \\
\text { usefulness of a } \\
\text { family booklet } \\
\text { about comfort } \\
\text { care in advanced } \\
\text { dementia aimed to } \\
\text { educate and } \\
\text { reassure family }\end{array}$ & $\begin{array}{l}\text { Postal } \\
\text { questionnaire }\end{array}$ & $\begin{array}{l}\text { Descriptive } \\
\text { and } \\
\text { inferential } \\
\text { analyses }\end{array}$ & $\begin{array}{l}\text { 1. The booklet was generally well } \\
\text { accepted with some variations among } \\
\text { countries; } \\
\text { 2. The majority of nurses felt the } \\
\text { booklet could be useful for the } \\
\text { majority of families to provide } \\
\text { education about end-of-life care in } \\
\text { advanced dementia; } \\
\text { 3. About three quarters or more of the } \\
\text { nurses indicated that the best moment } \\
\text { to provide the booklet was when there } \\
\text { are discussions about a medical } \\
\text { problem for which comfort care is an } \\
\text { option. }\end{array}$ & $7 / 9$ & $\begin{array}{l}\bullet \bullet \circ \circ \\
\text { Low }\end{array}$ \\
\hline $\begin{array}{l}\text { Ducharme, } \\
\text { Levesque, } \\
\text { Giroux, et } \\
\text { al., 2005 } \\
\text { (G) }\end{array}$ & Quantitative & $\begin{array}{l}\text { Randomized } \\
\text { controlled } \\
\text { trial }\end{array}$ & $\begin{array}{l}\text { Canada/ } 27 \\
\text { public NHs } \\
\text { (NR) }\end{array}$ & $\begin{array}{l}137 \text { daughters } \\
\begin{array}{l}\text { Experimental } \\
\text { psychoeducational } \\
\text { programme } \\
\text { entitled 'Taking } \\
\text { care of myself' } \\
(\mathrm{n}=45)\end{array} \\
\quad \text { Age }=57 \text { (6.5) } \\
\begin{array}{l}\text { Comparison } \\
\text { programme } \\
(\mathrm{n}=51)\end{array} \\
\begin{array}{l}\text { Age }=54.5 \\
(7.0)\end{array}\end{array}$ & $\begin{array}{l}\text { Family } \\
\text { caregivers' } \\
\text { psychological } \\
\text { distress, role } \\
\text { overload, stress } \\
\text { appraisal, coping } \\
\text { strategies, and } \\
\text { competence } \\
\text { dealing with } \\
\text { HCPs three } \\
\text { months after a } \\
\text { psychoeducational } \\
\text { programme }\end{array}$ & $\begin{array}{l}\text { Structured face- } \\
\text { to-face interview } \\
\text { with the } \\
\text { questionnaire } \\
\text { format two weeks } \\
\text { prior to the start } \\
\text { of the } \\
\text { programme, at the } \\
\text { end of the } \\
\text { programme, and } \\
\text { three months later }\end{array}$ & $\begin{array}{l}\text { Descriptive } \\
\text { and } \\
\text { inferential } \\
\text { analyses }\end{array}$ & $\begin{array}{l}\text { 1. At the 3-month follow up, a higher } \\
\text { proportion of family caregivers } \\
\text { undergoing some type of educational } \\
\text { programme reported less stress related } \\
\text { to their caregiving situation, more } \\
\text { frequent use of coping strategies, and } \\
\text { greater competence dealing with } \\
\text { HCPs compared to those family } \\
\text { caregivers who did not receive any } \\
\text { educational programme; instead, the } \\
\text { perception of less role overload was } \\
\text { not maintained; } \\
\text { 2. Outcomes non-significant at the end } \\
\text { of the programme failed to reach } \\
\text { significance at the 3-month follow up } \\
\text { as well. }\end{array}$ & $6 / 12$ & $\begin{array}{l}\bullet \bullet \bullet \circ \\
\text { Moderate }\end{array}$ \\
\hline
\end{tabular}




\begin{tabular}{|c|c|c|c|c|c|c|c|c|c|c|}
\hline & & & & $\begin{array}{l}\begin{array}{l}\text { No programme } \\
(\mathrm{n}=41)\end{array} \\
\quad \text { Age }=51.5 \\
(8.4)\end{array}$ & & & & & & \\
\hline $\begin{array}{l}\text { Ducharme, } \\
\text { Levesque, } \\
\text { Lachance, } \\
\text { et al., } 2005 \\
\text { (F) }\end{array}$ & Quantitative & $\begin{array}{l}\text { Randomized } \\
\text { controlled } \\
\text { trial }\end{array}$ & $\begin{array}{l}\text { Canada/ } 27 \\
\text { public NHs } \\
\text { (NR) }\end{array}$ & $\begin{array}{l}137 \text { daughters } \\
\begin{array}{l}\text { Experimental } \\
\text { psychoeducational } \\
\text { programme } \\
\text { entitled 'Taking } \\
\text { care of myself' } \\
(\mathrm{n}=45)\end{array} \\
\quad \text { Age }=57(6.5) \\
\begin{array}{l}\text { Comparison } \\
\text { programme } \\
(\mathrm{n}=51)\end{array} \\
\begin{array}{l}\text { Age }=54.5 \\
(7.0)\end{array} \\
\begin{array}{l}\text { No programme } \\
(\mathrm{n}=41)\end{array} \\
\begin{array}{l}\text { Age }=51.5 \\
(8.4)\end{array}\end{array}$ & $\begin{array}{l}\text { Family } \\
\text { caregivers' } \\
\text { psychological } \\
\text { distress, role } \\
\text { overload, stress } \\
\text { appraisal, coping } \\
\text { strategies (i.e., } \\
\text { problem solving, } \\
\text { reframing, and } \\
\text { stress } \\
\text { management), and } \\
\text { competence } \\
\text { dealing with } \\
\text { HCPs following a } \\
\text { psychoeducational } \\
\text { programme } \\
\\
\text { Family } \\
\text { caregivers' } \\
\text { perception of the } \\
\text { psychoeducational } \\
\text { programme } \\
\text { relevance in } \\
\text { producing } \\
\text { changes in their } \\
\text { daily life }\end{array}$ & $\begin{array}{l}\text { Structured face- } \\
\text { to-face interview } \\
\text { with the } \\
\text { questionnaire } \\
\text { format two weeks } \\
\text { prior to the start } \\
\text { of the programme } \\
\text { and at the end of } \\
\text { the programme } \\
\text { Semi-structured } \\
\text { open-ended } \\
\text { interview at the } \\
\text { end of the } \\
\text { programme }\end{array}$ & $\begin{array}{l}\text { Descriptive } \\
\text { and } \\
\text { inferential } \\
\text { analyses } \\
\\
\text { Undefined } \\
\text { qualitative } \\
\text { data } \\
\text { analysis }\end{array}$ & $\begin{array}{l}\text { 1. A higher proportion of family } \\
\text { caregivers undergoing some type of } \\
\text { educational programme reported less } \\
\text { role overload, less stress related to } \\
\text { their caregiving situation, more } \\
\text { frequent use of reframing, and greater } \\
\text { competence dealing with HCPs } \\
\text { compared to those family caregivers } \\
\text { who did not receive any educational } \\
\text { programme; no improvement in } \\
\text { psychological distress, problem } \\
\text { solving skills, and stress management; } \\
\text { 2. To communicate better with } \\
\text { their relative and to render their } \\
\text { visits more pleasant - 'I'm more } \\
\text { patient during the visits. I can follow } \\
\text { what my mother says instead of } \\
\text { frustrating her' (U); } \\
\text { 3. To express their point of view to } \\
\text { the nursing staff - 'Imanaged calmly } \\
\text { to let my dissatisfaction with my } \\
\text { mother's diet be known. We managed } \\
\text { to find ways of correcting the } \\
\text { situation' (U); } \\
\text { 4. To practise reframing - 'The } \\
\text { programme allowed me to step back } \\
\text { from my situation' (U); } \\
\text { 5. To reflect upon the acceptance of } \\
\text { loss - 'I became aware of how I } \\
\text { responded to loss and of my resources } \\
\text { for dealing with it' (U); } \\
\text { 6. To take care of myself - } \\
\text { 'Everything having to do with guilt . } \\
\text { it helped me a lot to change things in }\end{array}$ & $6 / 12$ & $\begin{array}{l}\bullet \bullet \bullet \circ \\
\text { Moderate }\end{array}$ \\
\hline
\end{tabular}




\begin{tabular}{|c|c|c|c|c|c|c|c|c|c|c|}
\hline & & & & & & & & $\begin{array}{l}\text { that regard and to try to dedicate more } \\
\text { time to me and my husband' (U); } \\
\text { 7. To become aware of their } \\
\text { strengths (empowerment) - 'I tell } \\
\text { myself that I'm able and I feel less } \\
\text { impotent' (U). }\end{array}$ & & \\
\hline $\begin{array}{l}\text { Moore et } \\
\text { al., 2020 } \\
\text { (E) }\end{array}$ & Quantitative & $\begin{array}{l}\text { Cross- } \\
\text { sectional }\end{array}$ & $\begin{array}{l}\text { UK/ } 44 \text { NHs, } \\
86 \% \text { Gold } \\
\text { Standard } \\
\text { Framework } \\
\text { accredited, } \\
77 \% \text { privately } \\
\text { owned, } 66 \% \\
\text { with between } \\
40-99 \text { beds }\end{array}$ & $\begin{array}{l}44 \mathrm{NH} \\
\text { managers/deputy } \\
\text { managers } \\
\text { Gender }= \\
\text { female } 38 \\
(86.4 \%) \\
\text { Age }=\mathrm{NR}\end{array}$ & $\begin{array}{l}\text { Practices adopted } \\
\text { to inform family } \\
\text { caregivers of } \\
\text { people with } \\
\text { dementia about } \\
\text { end of life }\end{array}$ & Online survey & $\begin{array}{l}\text { Descriptive } \\
\text { analyses }\end{array}$ & $\begin{array}{l}\text { 1. } 68.2 \% \text { ( } \mathrm{n}=30) \text { of survey participants } \\
\text { reported that family meetings were } \\
\text { offered to support family caregivers; } \\
\text { 2. Only } 3 \mathrm{NHs} \text { offered family } \\
\text { education sessions; } \\
\text { 3. Survey participants provided family } \\
\text { caregivers verbal discussions and } \\
\text { information about (i) dementia as a } \\
\text { progressive illness }(68.2 \%) \text {, a life- } \\
\text { shortening illness }(61.4 \%) \text {, disease } \\
\text { you can die from (59.1\%), and a } \\
\text { terminal illness (56.8\%); (ii) } \\
\text { spirituality or interpretation of the } \\
\text { meaning of death (59.1\%); (iii) } \\
\text { importance of support for family } \\
\text { caregivers from their social network } \\
\text { (63.6\%); (iv) meaning and } \\
\text { implications of loss of mental capacity } \\
\text { (72.7\%); (v) Advance Care Planning } \\
\text { discussions about patient's wishes for } \\
\text { the future (77.3\%); (vi) legal health } \\
\text { care attangements }(52.3 \%) \text {; and legal } \\
\text { financial arrangements (38.6\%); } \\
\text { 4. The provision of information in } \\
\text { leaflet form ranged according to the } \\
\text { topic: from } 20.5 \% \text { for the importance } \\
\text { of support for family caregivers from } \\
\text { their social network to } 68.2 \% \text { for } \\
\text { Advance Care Planning discussions } \\
\text { about patient's wishes for the future. }\end{array}$ & 9/9 & $\begin{array}{l}\bullet \bullet \circ 0 \\
\text { Low }\end{array}$ \\
\hline 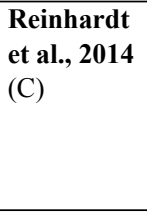 & Quantitative & $\begin{array}{l}\text { Randomized } \\
\text { controlled } \\
\text { trial with 6- } \\
\text { month } \\
\text { follow-up }\end{array}$ & $\begin{array}{l}\text { USA/ } 1 \text { large } \\
\text { skilled NH } \\
\text { (NR) }\end{array}$ & $\begin{array}{l}87 \text { family } \\
\text { caregivers } \\
\text { Intervention } \\
\text { group }(\mathrm{n}=47)\end{array}$ & $\begin{array}{l}\text { Family } \\
\text { caregivers' } \\
\text { depressive } \\
\text { symptoms and life } \\
\text { satisfaction } \\
\text { following a face- } \\
\end{array}$ & $\begin{array}{l}\text { Questionnaires } \\
\text { via telephone at } \\
\text { study entry, 3- } \\
\text { and 6-months } \\
\text { after }\end{array}$ & $\begin{array}{l}\text { Descriptive } \\
\text { and } \\
\text { inferential } \\
\text { analyses }\end{array}$ & $\begin{array}{l}\text { 1. Structured conversations with } \\
\text { follow-up calls hold by palliative care } \\
\text { physicians and social workers did not } \\
\text { have any significant effects on family } \\
\text { caregivers' depressive symptoms and }\end{array}$ & $8 / 11$ & $\begin{array}{l}\bullet \bullet \bullet \circ \\
\text { Moderate }\end{array}$ \\
\hline
\end{tabular}




\begin{tabular}{|c|c|c|c|c|c|c|c|c|c|c|}
\hline & & & & $\begin{array}{l}\text { Gender }= \\
\text { female } 37 \\
(78.7 \%) \\
\text { Age }=59.6 \\
(12.3) \\
\text { Kinship }=\text { child } \\
(\mathrm{n}=20), \text { spouse } \\
(\mathrm{n}=3), \text { friend } \\
(\mathrm{n}=4), \text { other } \\
(\mathrm{n}=20) \\
\\
\\
\\
\\
\text { Control group } \\
(\mathrm{n}=40) \\
\quad \begin{array}{l}\text { Gender }= \\
\text { female } 32 \\
(80.0 \%)\end{array} \\
\text { Age }=58.9 \\
(11.9) \\
\text { Kinship }=\text { child } \\
(\mathrm{n}=28), \text { spouse } \\
(\mathrm{n}=3), \text { friend } \\
(\mathrm{n}=1), \text { other }(\mathrm{n}=8)\end{array}$ & $\begin{array}{l}\text { to-face, structured } \\
\text { conversation } \\
\text { about end-of-life } \\
\text { care options for } \\
\text { their relative in } \\
\text { addition to 2- } \\
\text { month interval } \\
\text { follow-up calls }\end{array}$ & & & $\begin{array}{l}\text { life satisfaction neither no significant } \\
\text { effect by time. }\end{array}$ & & \\
\hline $\begin{array}{l}\text { Sabat et } \\
\text { al.., } 2010 \\
\text { (J) }\end{array}$ & Qualitative & $\begin{array}{l}\text { Longitudinal } \\
3 \text {-year case } \\
\text { study }\end{array}$ & $\begin{array}{l}\text { USA/ } 1 \mathrm{NH} \\
\text { (NR) }\end{array}$ & $\begin{array}{l}1 \text { wife } \\
\text { Age }=\mathrm{NR}\end{array}$ & $\begin{array}{l}\text { Dynamic } \\
\text { experience of a } \\
\text { spousal caregiver } \\
\text { receiving } \\
\text { education, } \\
\text { counseling and } \\
\text { psychosocial } \\
\text { support by email } \\
\text { and in-person } \\
\text { meetings }\end{array}$ & Email letters & $\begin{array}{l}\text { Undefined } \\
\text { qualitative } \\
\text { data } \\
\text { analysis }\end{array}$ & $\begin{array}{l}\text { 1. Understanding that she cannot fix } \\
\text { everything - 'Accepting the fact that } \\
\text { you cannot fix some things is a huge, } \\
\text { but necessary, step to take. Not to } \\
\text { accept what cannot be changed is just } \\
\text { not healthy or helpful in any way to } \\
\text { anyone. To work as best you can to } \\
\text { make things as good as they can be } \\
\text { within the limits that exist is a very, } \\
\text { very important thing to do' (U); } \\
\text { 2. Understanding and reducing her } \\
\text { emotional reactivity - 'You also told } \\
\text { me to stop resenting what was } \\
\text { happening in my life. That wasn't easy } \\
\text { either. However, though there are... }\end{array}$ & $7 / 7$ & $\begin{array}{l}\bullet \bullet \bullet \bullet \\
\text { High }\end{array}$ \\
\hline
\end{tabular}




\begin{tabular}{|c|c|c|c|c|c|c|c|c|c|c|}
\hline & & & & & & & & $\begin{array}{l}\text { times I do still resent what has } \\
\text { happened to [my husband], they are } \\
\text { less frequent, and on some days I can } \\
\text { almost believe there is a reason' (U); } \\
\text { 3. Reflections - 'With your help, I } \\
\text { stopped and thought about what I was } \\
\text { going to say and made sure I wanted } \\
\text { to respond in that way' (U); } \\
\text { 4. Flourishing - 'It is like I found } \\
\text { another person inside of me. I like the } \\
\text { person Ifound' (U). }\end{array}$ & & \\
\hline $\begin{array}{l}\text { Saini et al., } \\
2016 \text { (A) }\end{array}$ & Qualitative & Ethnografic & $\begin{array}{l}\mathrm{UK} / 2 \mathrm{NHs} \\
\text { (99 and } 77 \\
\text { beds, } \\
\text { respectively) }\end{array}$ & $\begin{array}{l}4 \text { family } \\
\text { caregivers (two } \\
\text { daughters, a } \\
\text { husband, and a } \\
\text { son, between the } \\
\text { ages of } 54 \text { and } 76) \\
19 \mathrm{HCPs} \\
\text { [healthcare } \\
\text { assistants ( } \mathrm{n}=6 \text { ), } \\
\text { deputy managers } \\
(\mathrm{n}=3) \text {, managers } \\
(\mathrm{n}=2) \text {, activity } \\
\text { co-ordinators }(\mathrm{n}= \\
\text { 2), general } \\
\text { practitioner }(\mathrm{n}= \\
\text { 2), nurses }(\mathrm{n}=2), \\
\text { palliative care } \\
\text { nurse }(\mathrm{n}=1) \text {, and } \\
\text { geriatrician }(\mathrm{n}=1)]\end{array}$ & $\begin{array}{l}\text { Practices relating } \\
\text { to end-of-life } \\
\text { discussions with } \\
\text { family caregivers } \\
\text { of NH residents } \\
\text { with advanced } \\
\text { dementia } \\
\\
\text { Strategies for } \\
\text { improving } \\
\text { practice of end-of- } \\
\text { life discussions }\end{array}$ & $\begin{array}{l}\text { Reflective diary } \\
\text { reporting } \\
\text { fieldwork notes } \\
\text { and observation } \\
\text { by an } \\
\text { interdisciplinary } \\
\text { care leader HCP } \\
\\
\text { Semi-structured } \\
\text { and open-ended } \\
\text { interviews with } \\
\text { family caregivers } \\
\text { (10 to } 25 \text { min in } \\
\text { length) and HCPs } \\
\text { (5 to } 35 \text { min in } \\
\text { length) }\end{array}$ & $\begin{array}{l}\text { Thematic } \\
\text { analysis }\end{array}$ & 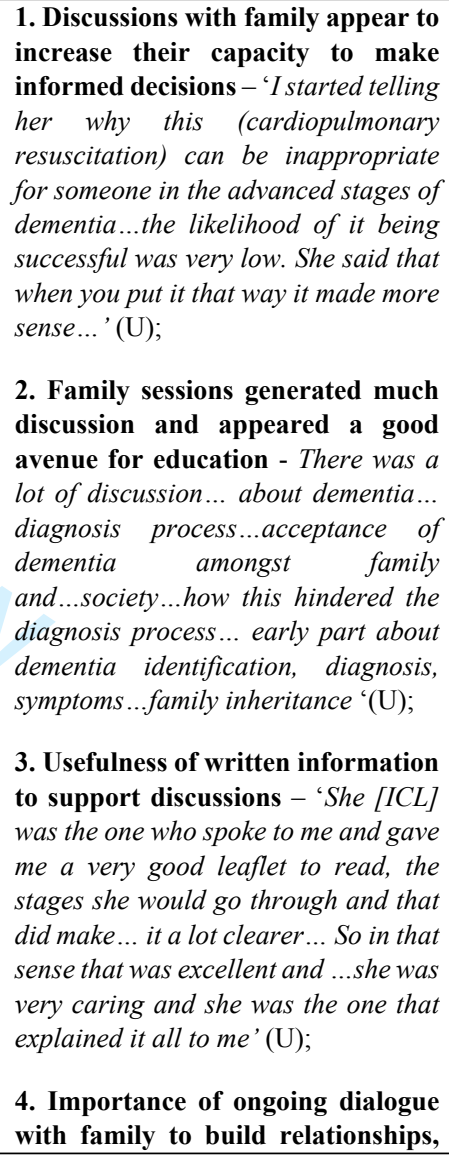 & $10 / 10$ & $\begin{array}{l}\bullet \bullet \bullet \bullet \\
\text { High }\end{array}$ \\
\hline
\end{tabular}




\begin{tabular}{|c|c|c|c|c|c|c|c|c|c|c|}
\hline & & & & & & & & $\begin{array}{l}\text { 8. Not suitable having sensitive } \\
\text { conversations with family in } \\
\text { communal areas such as lounge or } \\
\text { dining room - 'It is very difficult } \\
\text { having a conversation in the main } \\
\text { lounge with all the other residents..., } \\
\text { family members and staff in the room' } \\
\text { (U); } \\
\text { 9. Spending sufficient time with } \\
\text { family to address their questions } \\
\text { and explore their concerns, } \\
\text { including } \quad \text { follow-up } \\
\text { sessions/ongoing dialogue - 'I think } \\
\text { takes time; because it's not one that } \\
\text { you can do in one sitting. That often } \\
\text { you need to build the relationship and } \\
\text { then go it step by step. And I think } \\
\text { that's where [IILL] role is quite unique } \\
\text { in that she can come back and have a } \\
\text { second conversation, a third } \\
\text { conversation and a fourth if that is } \\
\text { required' (U); } \\
\text { 10. Having an independent } \\
\text { healthcare professional or team } \\
\text { with responsibility for end-of lifie } \\
\text { discussions - 'We feel it's helpful } \\
\text { because she has got a different way of } \\
\text { looking at the situation. The areas } \\
\text { where we don't normally see... it will } \\
\text { help and improve in the care of these } \\
\text { service users' (U). }\end{array}$ & & \\
\hline $\begin{array}{l}\text { van der } \\
\text { Steen, } \\
\text { Arcand, et } \\
\text { al., } 2012 \\
\text { (I) }\end{array}$ & Quantitative & $\begin{array}{l}\text { Cross- } \\
\text { sectional }\end{array}$ & $\begin{array}{l}\text { Italy/4 NHs } \\
\text { (NR) } \\
\text { Netherlands/ } \\
29 \text { NHs (NR) } \\
\text { Canada/ } 5 \\
\text { NHs }\end{array}$ & $\begin{array}{l}138 \text { bereaved } \\
\text { family caregivers } \\
\quad \text { Gender }= \\
\text { female } 98 \\
(71 \%) \\
\text { Age }=58.7- \\
61.1(7.7-12)\end{array}$ & $\begin{array}{l}\text { Family } \\
\text { caregivers, } \\
\text { perception of } \\
\text { acceptability and } \\
\text { usefulness of a } \\
\text { booklet about } \\
\text { comfort care in } \\
\text { advanced } \\
\text { dementia aimed at } \\
\text { their education } \\
\text { and reassurement }\end{array}$ & $\begin{array}{l}\text { Face-to-face } \\
\text { interview with the } \\
\text { questionnaire } \\
\text { format } \\
\text { Postal } \\
\text { questionnaire }\end{array}$ & \begin{tabular}{|l|} 
Descriptive \\
analyses \\
(SPSS \\
version \\
15.0 .1 )
\end{tabular} & $\begin{array}{l}\text { 1. The booklet was found highly } \\
\text { acceptable by Canadian and Dutch } \\
\text { family caregivers and acceptable by } \\
\text { Italian family caregivers; } \\
\text { 2. Almost all family caregivers (94\%) } \\
\text { perceived the booklet as useful; } \\
\text { 3. Those family caregivers not finding } \\
\text { the booklet useful stated that they } \\
\text { preferred talking over reading; } \\
\text { 4. There was large variation in } \\
\text { preference of when to obtain the }\end{array}$ & 9/9 & $\begin{array}{l}\bullet \bullet \bullet \bullet \\
\text { High }\end{array}$ \\
\hline
\end{tabular}




\begin{tabular}{|c|c|c|c|c|c|c|c|c|c|c|}
\hline & & & & & & & & $\begin{array}{l}\text { booklet, but the dying phase was the } \\
\text { least preferred time; } \\
\text { 5. Almost all family caregivers ( } 96 \% \text { - } \\
100 \% \text { ) accepted any HCPs to have a } \\
\text { role in providing the booklet and } \\
\text { about half ( } 42 \%-58 \% \text { ) endorsed } \\
\text { availability not through } \\
\text { practitioners. }\end{array}$ & & \\
\hline $\begin{array}{l}\text { van der } \\
\text { Steen, de } \\
\text { Grass, et } \\
\text { al., } 2011 \\
(\mathrm{~K})\end{array}$ & Quantitative & $\begin{array}{l}\text { Cross- } \\
\text { sectional }\end{array}$ & $\begin{array}{l}\text { Netherlands/ } \\
\text { NHs (NR) }\end{array}$ & $\begin{array}{l}30 \text { physicians } \\
\text { Gender }=\text { female } \\
19(63 \%) \\
\text { Age }=48(9) \\
38 \text { nurses } \\
\text { Gender }=\text { female } \\
36(95 \%) \\
\text { Age }=39(9) \\
59 \text { bereaved } \\
\text { family caregivers } \\
\quad \text { Gender }= \\
\text { female } 66 \% \\
\text { Age }=60(10) \\
\text { Kinship }=\text { child } \\
(\mathrm{n}=41), \text { spouse } \\
(\mathrm{n}=8) \text {, other } \\
(\mathrm{n}=10)\end{array}$ & $\begin{array}{l}\text { Physicians', } \\
\text { nurses' and family } \\
\text { caregivers' } \\
\text { perception of the } \\
\text { need, } \\
\text { acceptability and } \\
\text { usefulness of a } \\
\text { family booklet } \\
\text { about comfort } \\
\text { care in advanced } \\
\text { dementia aimed to } \\
\text { educate and } \\
\text { reassure family } \\
\text { caregivers }\end{array}$ & $\begin{array}{l}\text { Postal } \\
\text { questionnaire }\end{array}$ & 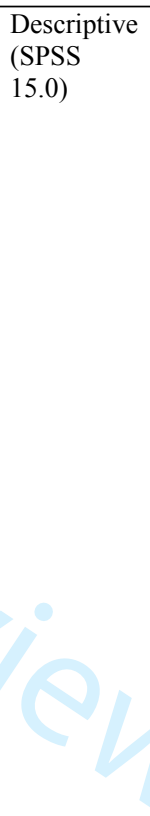 & $\begin{array}{l}\text { 1. All respondents reported a need of } \\
\text { written information about comfort } \\
\text { care and end-of-life issues for family } \\
\text { caregivers; } \\
\text { 2. High acceptability of the booklet for } \\
\text { nurses and family caregivers, } \\
\text { moderate to high acceptability for } \\
\text { physicians; } \\
\text { 3. The booklet was found useful by all } \\
\text { respondents; } \\
\text { 4. Variability in the preferred timing } \\
\text { of receiving the booklet among all } \\
\text { respondents with discrepancy between } \\
\text { family caregivers and physicians; } \\
\text { 5. All respondents agreed that HCPs } \\
\text { such as the attending physician or } \\
\text { nurse should have a role in providing } \\
\text { the booklet, and half favoured } \\
\text { availability also not through } \\
\text { practitioners. }\end{array}$ & $7 / 9$ & $\begin{array}{l}\bullet \bullet \circ \circ \\
\text { Low }\end{array}$ \\
\hline $\begin{array}{l}\text { van der } \\
\text { Steen, } \\
\text { Toscani, et } \\
\text { al., } 2011 \\
\text { (D) }\end{array}$ & Quantitative & $\begin{array}{l}\text { Cross- } \\
\text { sectional }\end{array}$ & $\begin{array}{l}\text { Italy/ } 14 \text { NHs } \\
\text { (NR) } \\
\text { Netherlands/ } \\
21 \text { NHs (NR) }\end{array}$ & $\begin{array}{l}87 \text { physicians } \\
\text { Gender }= \\
\text { female } 54 \\
(62.1 \%) \\
\text { Age }=46.3- \\
48.3(6.8-10) \\
\\
81 \text { nurses }\end{array}$ & $\begin{array}{l}\text { Physicians' and } \\
\text { nurses' perception } \\
\text { of acceptability } \\
\text { and usefulness of } \\
\text { a family booklet } \\
\text { about comfort } \\
\text { care in advanced } \\
\text { dementia aimed to } \\
\text { educate and } \\
\text { reassure family } \\
\text { caregivers }\end{array}$ & $\begin{array}{l}\text { Postal } \\
\text { questionnaire }\end{array}$ & 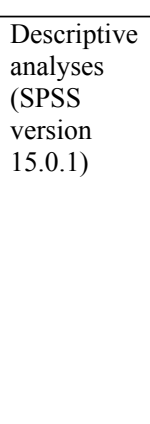 & $\begin{array}{l}\text { 1. Both Italian and Dutch HCPs found } \\
\text { the booklet acceptable with high } \\
\text { acceptability by Dutch nurses; } \\
\text { 2. HCPs' perception that a family } \\
\text { booklet about comfort care in } \\
\text { advanced dementia would be useful } \\
\text { for most families to make them } \\
\text { understand the risks and benefits of } \\
\text { care options and reassure those who } \\
\text { opt for comfort care that this is an } \\
\text { acceptable option and probably the }\end{array}$ & $9 / 9$ & $\begin{array}{l}\bullet \bullet \bullet \bullet \\
\text { High }\end{array}$ \\
\hline
\end{tabular}




\begin{tabular}{|c|c|c|c|c|c|c|c|c|c|c|}
\hline & & & & $\begin{array}{l}\text { Gender }= \\
\text { female } 75 \\
(92.6 \%) \\
\text { Age }=38.6-42 \\
(9.0-11.3)\end{array}$ & & & & $\begin{array}{l}\text { most appropriate one in advanced } \\
\text { dementia. }\end{array}$ & & \\
\hline $\begin{array}{l}\text { Stirling et } \\
\text { al., 2014 } \\
\text { (B) }\end{array}$ & Qualitative & Descriptive & $\begin{array}{l}\text { Australia/4 } \\
\text { NHs (NR) }\end{array}$ & $\begin{array}{l}5 \text { dementia care } \\
\text { nurses } \\
11 \text { family } \\
\text { caregivers }\end{array}$ & $\begin{array}{l}\text { Need for and } \\
\text { usefulness of a } \\
\text { booklet aimed to } \\
\text { aid talking about } \\
\text { dementia and } \\
\text { dying during } \\
\text { family meeting }\end{array}$ & $\begin{array}{l}\text { Open-ended } \\
\text { interviews with } \\
\text { family caregivers } \\
\text { (about one hour } \\
\text { in length) and } \\
\text { dementia nurses }\end{array}$ & $\begin{array}{l}\text { Thematic } \\
\text { analysis }\end{array}$ & $\begin{array}{l}\text { 1. Moving to engaged dialogue - 'I } \\
\text { found it [dementia dialogue] } \\
\text { beneficial because it enabled me to } \\
\text { ask a few questions and speak on a } \\
\text { more one to one basis than perhaps we } \\
\text { would otherwise. . than we do in the } \\
\text { [traditional] care plan meetings' (U); } \\
\text { 2. Providing a format for discussion } \\
\text { of future care needs - '...we did talk } \\
\text { about palliative care and I said, yes, } \\
\text { here. There's no need to go the } \\
\text { [hospital]' (U). }\end{array}$ & $8 / 10$ & $\begin{array}{l}\bullet \bullet \bullet \circ \\
\text { Moderate }\end{array}$ \\
\hline
\end{tabular}

Abbrewans: HCP, Healthcare profes

The progressive letters next to author(s)' name indicate the order of study inclusion in the review, while the progressive numbers within the column of findings indicate the order of findings in the original article.

Age is reported as mean $(\mathrm{SD})$

Studies code: $\mathrm{A},{ }^{44} \mathrm{~B},{ }^{48} \mathrm{C},{ }^{45} \mathrm{D},{ }^{52} \mathrm{E},{ }^{43} \mathrm{~F},{ }^{38} \mathrm{G},{ }^{47} \mathrm{H},{ }^{50} \mathrm{I},{ }^{51} \mathrm{~J},{ }^{46} \mathrm{~K}^{49}$ 
Table 2: Description of interventions provided to family caregivers of people with advanced dementia at the end of life in nursing home and their contribution to integrated findings

\begin{tabular}{|c|c|c|}
\hline Author(s), year (code) & Intervention & $\begin{array}{l}\text { Contribution to } \\
\text { integreted finding(s) }\end{array}$ \\
\hline \multicolumn{3}{|l|}{ Provision of information $(n=5)$} \\
\hline Arcand et al., $2013(\mathrm{H})$ & $\begin{array}{l}\text { Nurses working in long-term care settings were asked to rate the acceptability and usefulness of a booklet which } \\
\text { informed on the course of the dementia, expected complications, the decision-making process, symptom } \\
\text { management, dying, and grief. }\end{array}$ & 2 \\
\hline Moore et al., $2020(\mathrm{E})$ & $\begin{array}{l}\text { Online survey among a random sample of nursing homes with Gold Standards Framework in Care Homes } \\
\text { accreditation. The survey explored the current practice regarding information provided by the service (e.g., } \\
\text { dementia progression, the terminal nature of dementia, spirituality, mental capacity, end-of-life preferences, and legal } \\
\text { arrangements) and the format of this information (in direct discussion with the person with dementia or carer, in a } \\
\text { group setting or in written format). }\end{array}$ & 2 and 3 \\
\hline $\begin{array}{l}\text { van der Steen, Arcand, et al., } \\
2012 \text { (I) }\end{array}$ & $\begin{array}{l}\text { Family caregivers were asked to rate the acceptability and usefulness of a booklet which informed on the course of } \\
\text { the dementia, expected complications, the decision-making process, symptom management, dying, and grief. }\end{array}$ & 2 \\
\hline $\begin{array}{l}\text { van der Steen, de Grass, et } \\
\text { al., } 2011(\mathrm{~K})\end{array}$ & $\begin{array}{l}\text { Family caregivers, physicians, and nurses were asked to rate the need, acceptability and usefulness of a booklet } \\
\text { which informed on the course of the dementia, expected complications, the decision-making process, symptom } \\
\text { management, dying, and grief. }\end{array}$ & 2 \\
\hline $\begin{array}{l}\text { van der Steen, Toscani, et } \\
\text { al., } 2011 \text { (D) }\end{array}$ & $\begin{array}{l}\text { Physicians and nurses were asked to rate the acceptability and usefulness of a booklet which informed on the course } \\
\text { of the dementia, expected complications, the decision-making process, symptom management, dying, and grief. }\end{array}$ & 2 \\
\hline \multicolumn{3}{|c|}{ Psychoeducational programmes $(n=2)$} \\
\hline $\begin{array}{l}\text { Ducharme, Levesque, } \\
\text { Giroux, et al., } 2005(\mathrm{G})^{\mathrm{a}}\end{array}$ & $\begin{array}{l}\text { Family caregivers participated in a psychoeducational group programme called 'Taking Care of Myself'. This } \\
\text { programme consists of } 10 \text { 90-minute weekly sessions for groups of six to eight caregivers. It covers the following } \\
\text { six themes: (1) how to feel at ease with my relative; (2) how to express my point of view to health care staff; (3) how } \\
\text { to avoid emotional torment; (4) how to deal with small daily losses and prepare myself for the ultimate loss of my } \\
\text { relative; (5) how to identify and call upon my support network and community services; and (6) how to reorganize } \\
\text { my life after my relative moves to a nursing home and take care of myself. A participatory approach is used (e.g. } \\
\text { discussions, written exercises between sessions, role playing), centred on the actual concerns of caregivers in order } \\
\text { to foster transfer of the strategies learned. }\end{array}$ & 1 and 3 \\
\hline $\begin{array}{l}\text { Ducharme, Levesque, } \\
\text { Lachance, et al., } 2005(\mathrm{~F})^{\mathrm{a}}\end{array}$ & $\begin{array}{l}\text { Family caregivers underwent a psychoeducational group programme called 'Taking Care of Myself’. For details } \\
\text { see Ducharme, Levesque, Giroux, et al., } 2005(\mathrm{G}) .\end{array}$ & 3 \\
\hline \multicolumn{3}{|c|}{ Family meetings associated with written information $(n=1)$} \\
\hline Stirling et al., 2014 (B) & $\begin{array}{l}\text { Family caregivers of people living with dementia were invited to a family meeting held by the resource nurse of the } \\
\text { facility. A booklet was employed as a meeting guide to facilitate discussion about a resident's dementia and disease } \\
\text { trajectory. The booklet included information about the need for a palliative approach in dementia, guidance for }\end{array}$ & 1 and 2 \\
\hline
\end{tabular}




\begin{tabular}{|c|c|c|}
\hline & $\begin{array}{l}\text { communicating with families about death and a palliative approach, and advice to support the 'real world' situations } \\
\text { faced by nursing home staff. }\end{array}$ & \\
\hline Reinhardt et al., 2014 (C) & $\begin{array}{l}\text { The intervention was delivered by a palliative care team which included two certified palliative medicine physicians } \\
\text { and a palliative care social worker. A structured, face-to-face meeting with an "ask-tell-ask" model was employed. } \\
\text { Family members were asked what they understood about dementia, where they think their relative is in the disease } \\
\text { process, and what they expect as the disease progresses. Further, the physician shared the assessment of the resident's } \\
\text { condition, and the palliative care team discussed the family's goals of care for the resident, made recommendations } \\
\text { of how to achieve those goals, and provided psychosocial support, such as empathic and active listening and } \\
\text { rephrasing. These meetings took an average of } 47 \text { minutes (range } 20-75 \text { minutes) and included the following topics: } \\
\text { (a) resuscitation, (b) hospitalization, (c) artificial nutrition and hydration, and (d) pain and symptom management. } \\
\text { As part of the intervention, the palliative care social worker delivered a telephone follow-up every } 2 \text { months for six } \\
\text { months to address family caregivers' potential concerns about their relative. Each of these three telephone calls lasted } \\
\text { an average of } 10 \text { minutes. }\end{array}$ & 3 \\
\hline \multicolumn{3}{|c|}{ Family meetings associated with educational programmes $(n=1)$} \\
\hline Saini et al., 2016 (A) & $\begin{array}{l}\text { An interdisciplinary care leader with social science background and experienced in working with people with severe } \\
\text { dementia delivered the intervention, which has two core components: (i) facilitation of integrated care for people } \\
\text { with advanced dementia and (ii) training and support for those working with and caring for people with advanced } \\
\text { dementia. } \\
\text { To facilitate integrated care, the leader attended weekly meetings with nursing home nurses and when possible the } \\
\text { general practitioner. In these meetings residents' care needs were discussed, the need for external referral reviewed } \\
\text { and end-of-life plans agreed. Wider multidisciplinary team meetings were conducted on a monthly basis. Discussions } \\
\text { with family covered concerns raised by the family, common symptoms in advanced dementia, end-of-life care and } \\
\text { whether the family member was coping or needed more support. The leader ran formal training sessions for staff } \\
\text { and family and informal on-the-job advice and support. Staff training sessions covered behavioural symptoms, pain } \\
\text { management and end of life, and family sessions covered the trajectory of dementia, common end-of-lfie symptoms } \\
\text { and the personal experiences of care. }\end{array}$ & 1,2 , and 3 \\
\hline \multicolumn{3}{|c|}{ Family meetings associated with written information, psychological support, and education $(\mathrm{n}=1)$} \\
\hline Sabat et al., $2010(\mathrm{~J})$ & $\begin{array}{l}\text { Email communication over a 3-year period with a total of } 1276 \text { letters, averaging approximately } 38 \text { per month, } \\
\text { between the wife of a man with dementia and a psychologist. Letters informed the spousal caregiver about a variety } \\
\text { of issues, including aspects of her husband's memory and selfhood, how she could interact with him to their mutual } \\
\text { advantage, her husband's subjective experience of, and his reactions to, the losses he was experiencing, and how his } \\
\text { responses affected her. Frequent email communication constituted the main source of education, counseling } \\
\text { and psychosocial support. This information was associated with in-person meetings which occurred every three to } \\
\text { four months to help the spousal caregiver to understand her husband's condition more clearly, interact with him more } \\
\text { effectively, and gain a measure of control over what was happening in their lives. }\end{array}$ & \\
\hline
\end{tabular}

${ }^{2}$ Data collected on the same cohort of patients

The progressive letters next to author(s)' name indicate the order of study inclusion in the review.
Studies code: $\mathrm{A},{ }^{44} \mathrm{~B},{ }^{48} \mathrm{C},{ }^{45} \mathrm{D},{ }^{52} \mathrm{E},{ }^{43} \mathrm{~F},{ }^{88} \mathrm{G},{ }^{47} \mathrm{H},{ }^{50} \mathrm{I},{ }^{51} \mathrm{~J},{ }^{46} \mathrm{~K}^{49}$ 
Table 3: Integrated findings, categories and qualitized and qualitative findings extracted from the included studies

Qualitized (QZ) and qualitative (QT) findings (alphanumeric code)

QT. Discussions with family appear to increase their capacity to make

informed decisions (A1)

QT. Importance of ongoing dialogue with family to build relationships, provide reassurance and allow time for family to process information (A4)

QT. Moving to engaged dialogue (B1)

QT. To communicate better with their relative and to render their visits more pleasant (F2)

QT. Understanding and reducing her emotional reactivity (J2)

QT. Spending sufficient time with family to address their questions and

explore their concerns, including follow-up sessions/ongoing dialogue

(A9)

QT. To express their point of view to the nursing staff (F3)

QT. Importance of information provided in a sensitive way (A7)

QT. Not suitable having sensitive conversations with family in

communal areas such as lounge or dining room (A8)

QT. Need to acknowledge family members' grief and guilt (A6)

QT. Importance of addressing family member's current issues and concerns before discussing future plans (A5)

QT. Having an independent healthcare professional or team with responsibility for EOL discussions (A10)

QT. Usefulness of written information to support discussions (A3)

QT. Providing a format for discussion of future care needs (B2)

QZ. HCPs find a booklet about comfort care in advanced dementia acceptable (D1)

QZ. HCPs perceive that a family booklet about comfort care in advanced dementia would be useful for most families (D2)

QZ. Difference in the provision of information in leaflet form according to the topic (E4)

QZ. A booklet about comfort care in advanced dementia is well accepted among countries $(\mathrm{H} 1)$

QZ. The majority of nurses feel a booklet about comfort care in advanced dementia could be useful for the majority of families to provide education about EOL care in advanced dementia $(\mathrm{H} 2)$

QZ. Family caregivers find a booklet about comfort care in advanced dementia acceptable to highly acceptable (I1)

QZ. Almost all family caregivers perceive the booklet about comfort care in advanced dementia as useful (I2)

\section{Categories}

1. Ongoing discussion between healthcare professionals and family caregivers is pivotal to promote informed decisions, establish a partnership, provide emotional support and improve the relationship between family caregivers and their relative at the end-of-life

\section{Consideration of the manner and location} when discussing with family caregivers about their relative's end-of-life care preferences is important

3. End-of-life discussions should be face-toface, structured around a set of pre-defined topics and supported by written information to educate and reassure family caregivers

about care options at the end of life

\section{Integrated findings}

1. End-of-life dialogue should

be ongoing and provide

adequate time and space for

sensitive discussion to

establish a family caregivers-

healthcare professionals

partnership, promote shared

decision-making and improve

the quality of family

caregivers' remaining time

with their relative while

offering emotional support

2. End-of-life discussions

should be face-to-face and

guided by supporting written

information whose provision

may vary in timing and way

according to family

caregivers' preferences and

the context 
QZ. Most NHs provide family caregivers verbal discussions and informations (E3)

QZ. All physicians, nurses and family caregivers report family caregivers' need of written information about comfort care and EOL issues (K1)

QZ. High acceptability of the booklet for nurses and family caregivers, moderate to high acceptability for physicians (K2)

QZ. Physicians, nurses and family caregivers find the booklet about comfort care in advanced dementia as useful (K3)

QZ. Family caregivers not finding useful a booklet about comfort care in advanced dementia prefer talking over reading (I3)

QZ. Most nurses indicate that the best moment to provide the booklet is when there are discussions about a medical problem for which comfort care is an option (H3)

QZ. There is large variation among family caregivers in preference of when to obtain a booklet about comfort care in advanced dementia, but the dying phase is the least preferred time (I4)

QZ. Variability in the preferred timing of receiving the booklet about comfort care in advanced dementia among physicians, nurses and family caregivers with discrepancy between family caregivers and physicians (K4)

QZ. Almost all family caregivers accept any HCPs in providing the booklet and about half endorse availability not through practitioners (I5) QZ. Physicians, nurses and family caregivers agree that HCPs such as the attending physician or nurse should have a role in providing the booklet, and half favour availability also not through practitioners (K5) QZ. Structured conversations with follow-up calls hold by palliative care physicians and social workers did not have any significant effects on family caregivers' depressive symptoms and life satisfaction neither no significant effect by time $(\mathrm{C} 1)$

QZ. Family caregivers undergoing some type of educational programme report less role overload, less stress related to their caregiving situation, more frequent use of reframing, and greater competence dealing with

HCPs; no improvement in psychological distress, problem solving skills, and stress management (F1)

QZ. Some months after some type of educational programme, family caregivers continue to report less stress related to their caregiving

situation, more frequent use of coping strategies, and greater competence dealing with HCPs, while the perception of less role overload is not maintained (G1)
4. Consideration of when to provide written information about care options at the end of life and how to make them available to family caregivers is essential

5. Psychoeducational programmes and/or regular family meetings are needed to effectively relieve family caregivers' strain while just one meeting or simply providing information is not enough; involvement of professionals experienced in psychological care may be required to help family caregivers manage their psychological distress and develop problem solving skills

re
3. Family caregivers should be offered tailored

psychoeducational

programmes and/or regular

family meetings about

dementia care at the end of

life according to their specific

information and emotional

needs to promote

understanding about their

ative's health conditions,

ass, and empowerment in

facing challenging end-of-life- 
QZ. Outcomes non-significant at the end of the educational programme do not improve in the following months (G2)

QT. Flourishing (J4)

QZ. Most NHs offer family meetings to support family caregivers (E1)

QZ. A few NHs offer family education sessions (E2)

QT. Family sessions generated much discussion and appeared a good

avenue for education (A2)

QT. Having an independent healthcare professional or team with responsibility for EOL discussions (A10)

QT. To practise reframing (F4)

QT. Reflections (J3)

QT. Understanding that she cannot fix everything (J1)

QT. To take care of myself (F6)

QT. To become aware of their strengths (empowerment) (F7)

QT. To reflect upon the acceptance of loss (F5)

The

Note. The progressive letters indicate the order of study inclusion in the review, while the progressive numbers indicate the order of findings in the original article.

Studies code: $\mathrm{A}^{44} \mathrm{~B}^{48} \mathrm{C}^{45} \mathrm{D}^{52} \mathrm{E}^{43} \mathrm{~F}^{38} \mathrm{G}^{47} \mathrm{H}^{50} \mathrm{I}^{51} \mathrm{~J}^{46} \mathrm{~K}^{49}$

6. Interaction with peers and healthcare professionals independent from the staff of

the nursing home is useful to bring out

family caregivers' needs of education and

can be a source of emotional support

7. Family caregivers should be helped to

take care of themselves by promoting

reflection, reframing, acceptance, and finally

empowerment 


\section{Appendix}

This supplementary material is provided by the authors to give readers additional information about the systematic review and synthesis.

Appendix 1: Synthesis Without Meta-analysis (SWiM) guidelines .........................................................2

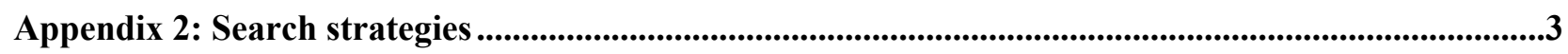

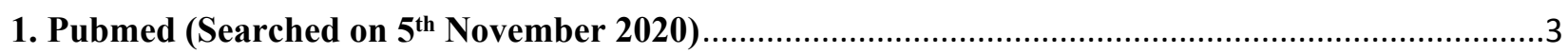

2. EBSCO CINAHL (Searched on $5^{\text {th }}$ November 2020).................................................................

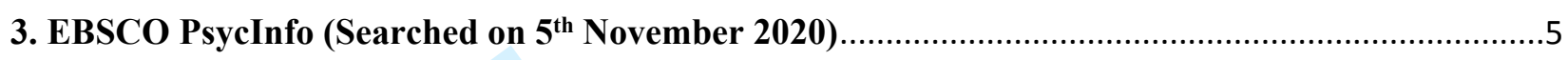

4. Joanna Briggs Institute (Searched on $5^{\text {th }}$ November 2020) …....................................................

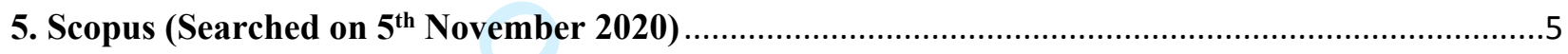

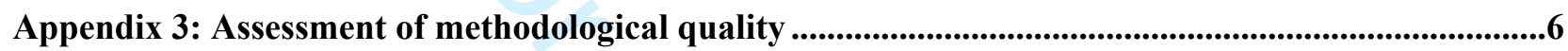

Appendix 3a: Assessment of methodological quality: survey designs reporting frequencies/proportions ${ }^{\mathrm{a}} . .6$

Appendix 3b: Assessment of methodological quality: randomized controlled trials ${ }^{\mathrm{a}}$..............................

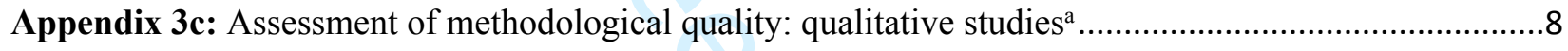

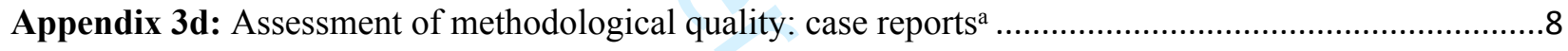

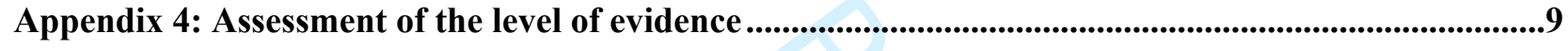

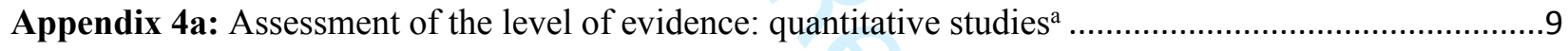

Appendix 4b: Assessment of the level of evidence: qualitative studies ${ }^{\mathrm{a}}$..............................................10

Appendix 4c: Assessment of the level of evidence: integrated findings ${ }^{\mathrm{a}}$.............................................10 


\section{Appendix 1: Synthesis Without Meta-analysis (SWiM) guidelines}

\begin{tabular}{|c|c|c|c|}
\hline \multicolumn{4}{|c|}{ SWiM is intended to complement and be used as an extension to PRISMA } \\
\hline $\begin{array}{l}\text { SWiM reporting } \\
\text { item }\end{array}$ & Item description & $\begin{array}{l}\text { Page in manuscript } \\
\text { where item is } \\
\text { reported }\end{array}$ & Other* \\
\hline \multicolumn{4}{|l|}{ Methods } \\
\hline \multirow{2}{*}{$\begin{array}{l}1 \text { Grouping } \\
\text { studies for } \\
\text { synthesis }\end{array}$} & $\begin{array}{l}\text { 1a) Provide a description of, and rationale for, the groups } \\
\text { used in the synthesis (e.g., groupings of populations, } \\
\text { interventions, outcomes, study design) }\end{array}$ & 8 & \\
\hline & $\begin{array}{l}\text { 1b) Detail and provide rationale for any changes made } \\
\text { subsequent to the protocol in the groups used in the } \\
\text { synthesis }\end{array}$ & $\begin{array}{c}\text { No changes made to } \\
\text { the protocol }\end{array}$ & \\
\hline $\begin{array}{l}2 \text { Describe the } \\
\text { standardised } \\
\text { metric and } \\
\text { transformation } \\
\text { methods used }\end{array}$ & $\begin{array}{l}\text { Describe the standardised metric for each outcome. } \\
\text { Explain why the metric(s) was chosen, and describe any } \\
\text { methods used to transform the intervention effects, as } \\
\text { reported in the study, to the standardised metric, citing any } \\
\text { methodological guidance consulted }\end{array}$ & 8 & \\
\hline $\begin{array}{l}3 \text { Describe the } \\
\text { synthesis } \\
\text { methods }\end{array}$ & $\begin{array}{l}\text { Describe and justify the methods used to synthesise the } \\
\text { effects for each outcome when it was not possible to } \\
\text { undertake a meta-analysis of effect estimates }\end{array}$ & 8 & \\
\hline $\begin{array}{l}4 \text { Criteria used } \\
\text { to prioritise } \\
\text { results for } \\
\text { summary and } \\
\text { synthesis }\end{array}$ & $\begin{array}{l}\text { Where applicable, provide the criteria used, with } \\
\text { supporting justification, to select the particular studies, or } \\
\text { a particular study, for the main synthesis or to draw } \\
\text { conclusions from the synthesis (e.g., based on study } \\
\text { design, risk of bias assessments, directness in relation to } \\
\text { the review question) }\end{array}$ & 7 & \\
\hline $\begin{array}{l}5 \text { Investigation } \\
\text { of } \\
\text { heterogeneity in } \\
\text { reported effects }\end{array}$ & $\begin{array}{l}\text { State the method(s) used to examine heterogeneity in } \\
\text { reported effects when it was not possible to undertake a } \\
\text { meta-analysis of effect estimates and its extensions to } \\
\text { investigate heterogeneity }\end{array}$ & $\begin{array}{l}\text { Not applicable. } \\
\text { Quantitative data was } \\
\text { converted into } \\
\text { 'qualitized data' and a } \\
\text { qualitative synthesis } \\
\text { performed }\end{array}$ & \\
\hline $\begin{array}{l}6 \text { Certainty of } \\
\text { evidence }\end{array}$ & $\begin{array}{l}\text { Describe the methods used to assess certainty of the } \\
\text { synthesis findings }\end{array}$ & $8-9$ & \\
\hline $\begin{array}{l}7 \text { Data } \\
\text { presentation } \\
\text { methods }\end{array}$ & $\begin{array}{l}\text { Describe the graphical and tabular methods used to present } \\
\text { the effects (e.g., tables, forest plots, harvest plots) } \\
\text { Specify key study characteristics (e.g., study design, risk of } \\
\text { bias) used to order the studies, in the text and any tables or } \\
\text { graphs, clearly referencing the studies included }\end{array}$ & 7 & \\
\hline \multicolumn{4}{|l|}{ Results } \\
\hline 8 Reporting results & $\begin{array}{l}\text { For each comparison and outcome, provide a description of } \\
\text { the synthesised findings, and the certainty of the findings. } \\
\text { Describe the result in language that is consistent with the } \\
\text { question the synthesis addresses, and indicate which } \\
\text { studies contribute to the synthesis }\end{array}$ & $\begin{array}{l}\text { 11-15, Table } 1, \\
\text { Table } 2, \\
\text { Figure } 2\end{array}$ & \\
\hline \multicolumn{4}{|l|}{ Discussion } \\
\hline $\begin{array}{l}9 \text { Limitations of the } \\
\text { synthesis }\end{array}$ & $\begin{array}{l}\text { Report the limitations of the synthesis methods used and/or } \\
\text { the groupings used in the synthesis, and how these affect } \\
\text { the conclusions that can be drawn in relation to the original } \\
\text { review question }\end{array}$ & 18 & \\
\hline
\end{tabular}

PRISMA=Preferred Reporting Items for Systematic Reviews and Meta-Analyses

* If the information is not provided in the systematic review, give details of where this information is available (e.g., protocol, other published papers (provide citation details), or website (provide the URL)). 


\section{Appendix 2: Search strategies}

\section{Pubmed (Searched on $5^{\text {th }}$ November 2020)}

\begin{tabular}{|c|c|c|}
\hline Search & Query & Items \\
\hline$\# 1$ & $\begin{array}{l}\text { next of kin*[Title/Abstract] OR "Spouses"[Mesh] OR "Family"[Mesh] OR "Caregivers"[Mesh] OR } \\
\text { "Siblings"[Mesh] OR Adult Children [Mesh] OR child[Title/Abstract] OR children[Title/Abstract] OR } \\
\text { wife[Title/Abstract] OR wives[Title/Abstract]) OR niece*[Title/Abstract] OR nephew*[Title/Abstract] } \\
\text { OR husband*[Title/Abstract] OR relative* [Title/Abstract] OR surrogate*[Title/Abstract] OR } \\
\text { grandchild[Title/Abstract] OR grandchildren[Title/Abstract] OR carer }{ }^{*} \text { [Title/Abstract] OR friend* } \\
\text { [Title/Abstract] OR neighbor*[Title/Abstract] }\end{array}$ & $3,073,235$ \\
\hline \#2 & 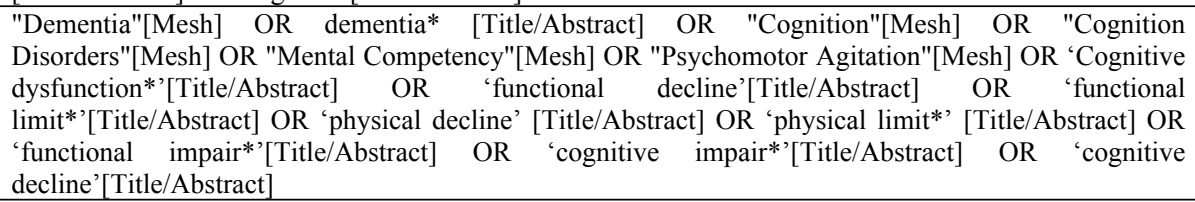 & 437,070 \\
\hline \#3 & $\begin{array}{l}\text { "Education"[Mesh] OR ‘Training Program*’[Title/Abstract] OR ‘Educational Activit*’[Title/Abstract] } \\
\text { OR 'information provision'[Title/Abstract] OR Information[Title/Abstract] OR “Teach-Back } \\
\text { Communication"[Mesh] OR "Health Communication"[Mesh] OR "Social Support"[Mesh] OR } \\
\text { "Counseling"[Mesh] OR 'Psychosocial support*' [Title/Abstract] OR "Emotional Adjustment"[Mesh] OR } \\
\text { "Mind-Body Therapies"[Mesh] OR "Mental Health/prevention and control"[Mesh] OR "Behavior } \\
\text { Therapy"[Mesh] OR 'Behavior modification*' [Title/Abstract] OR "Stress, Psychological/prevention and } \\
\text { control"[Mesh] OR 'psychoeducation*' [Title/abstract] OR 'psycho-education*' [Title/abstract] }\end{array}$ & $2,168,881$ \\
\hline \#4 & $\begin{array}{l}\text { ("Nursing Homes"[Mesh] OR "Homes for the Aged"[Mesh] OR "Long-Term Care"[Mesh] OR residential } \\
\text { care home*[Title/Abstract] OR long term facilit*[Title/Abstract]) }\end{array}$ & 66,469 \\
\hline$\# 5$ & $\begin{array}{l}\text { (next of kin*[Title/Abstract] OR "Spouses"[Mesh] OR "Family"[Mesh] OR "Caregivers"[Mesh] OR } \\
\text { "Siblings"[Mesh] OR Adult Children [Mesh] OR child[Title/Abstract] OR children[Title/Abstract] OR } \\
\text { wife[Title/Abstract] OR wives[Title/Abstract]] OR niece*[Title/Abstract] OR nephew*[Title/Abstract] } \\
\text { OR husband*[Title/Abstract] OR relative* [Title/Abstract] OR surrogate*[Title/Abstract] OR } \\
\text { grandchild[Title/Abstract] OR grandchildren[Title/Abstract] OR carer* [Title/Abstract] OR friend* } \\
\text { [Title/Abstract] OR neighbor*[Title/Abstract]) AND ("Dementia"[Mesh] OR dementia* [Title/Abstract] } \\
\text { OR "Cognition"[Mesh] OR "Cognition Disorders"[Mesh] OR "Mental Competency"[Mesh] OR } \\
\text { "Psychomotor Agitation"[Mesh] OR 'Cognitive dysfunction*'[Title/Abstract] OR 'functional } \\
\text { decline'[Title/Abstract] OR 'functional limit*'[Title/Abstract] OR 'physical decline' [Title/Abstract] OR } \\
\text { 'physical limit* [Title/Abstract] OR 'functional impair*'[Title/Abstract] OR "cognitive } \\
\text { impair*'[Title/Abstract] OR 'cognitive decline'[Title/Abstract]) AND ("Education"[Mesh] OR 'Training } \\
\text { Program*'[Title/Abstract] OR 'Educational Activit*'[Title/Abstract] OR 'information } \\
\text { provision'[Title/Abstract] OR Information[Title/Abstract] OR “Teach-Back Communication"[Mesh] OR } \\
\text { "Health Communication"[Mesh] OR "Social Support"[Mesh] OR "Counseling"[Mesh] OR 'Psychosocial } \\
\text { support*' [Title/Abstract] OR "Emotional Adjustment"[Mesh] OR "Mind-Body Therapies"[Mesh] OR } \\
\text { "Mental Health/prevention and control"[Mesh] OR "Behavior Therapy"[Mesh] OR 'Behavior } \\
\text { modification*' [Title/Abstract] OR "Stress, Psychological/prevention and control"[Mesh]) AND } \\
\text { (("Nursing Homes"[Mesh] OR "Homes for the Aged"[Mesh] OR "Long-Term Care"[Mesh] OR residential } \\
\text { care home*[Title/Abstract] OR long term facilit*[Title/Abstract]) }\end{array}$ & 432 \\
\hline
\end{tabular}




\section{EBSCO CINAHL (Searched on $5^{\text {th }}$ November 2020)}

\begin{tabular}{|c|c|c|c|}
\hline Search ID & Search Terms & Search Options & Actions \\
\hline \multirow[t]{2}{*}{ S5 } & \multirow[t]{2}{*}{ S1 AND S2 AND S3 AND S4 } & $\begin{array}{l}\text { Limiters - Exclude MEDLINE } \\
\text { records }\end{array}$ & \multirow[t]{2}{*}{312} \\
\hline & & Search modes - Boolean/Phrase & \\
\hline S5 & S1 AND S2 AND S3 AND S4 & Search modes - Boolean/Phrase & 627 \\
\hline S4 & $\begin{array}{l}\text { MH ("Education" OR "Support, Psychosocial+" OR "Counseling+" } \\
\text { OR "Emotional Support (Iowa NIC)" OR "Emotional Support (Saba } \\
\text { CCC)" OR "Mind Body Techniques" OR "Mental Health Care (Saba } \\
\text { CCC)" OR "Mental Health Promotion (Saba CCC)" OR "Behavior } \\
\text { Therapy" OR "Cognitive Therapy" OR "Behavior Modification" OR } \\
\text { "Stress, Psychological/PC" OR "Psychoeducation") OR AB } \\
\text { ("Training Program*” OR "Educational Activit*" OR "information" } \\
\text { OR "Teach-Back Communication" OR "Psychosocial support*” OR } \\
\text { "psychoeducation*" OR "psycho-education*”) OR TI (“Training } \\
\text { Program*” OR "Educational Activit*" OR "information" OR } \\
\text { "Teach-Back Communication" OR "Psychosocial support*” OR } \\
\text { "psychoeducation*" OR "psycho-education*”) }\end{array}$ & Search modes - Boolean/Phrase & 560,568 \\
\hline S3 & $\begin{array}{l}\text { MH ("Nursing Home Patients" OR "Nursing Homes" OR "Long } \\
\text { Term Care" OR "Residential Facilities") OR AB ("homes for } \\
\text { aged" OR "residential care" OR "nursing home*" OR "residential } \\
\text { care home*" OR "long term facilt*") OR TI ("homes for aged" OR } \\
\text { "residential care" OR "nursing home*" OR "residential care home*" } \\
\text { OR "long term facilt*") }\end{array}$ & Search modes - Boolean/Phrase & 65,780 \\
\hline $\mathrm{S} 2$ & $\begin{array}{l}\text { MH ("Dementia+" OR "Cognition Disorders+" OR "Cognition } \\
\text { (Omaha)" OR "Mental Disorders" OR "Psychomotor Agitation+") } \\
\text { OR AB (dementia OR "cognitive dysfunction" OR "functional } \\
\text { decline" OR "functional limit*" OR "physical decline" OR } \\
\text { "physical limit*" OR "functional impair*" OR "cognitive impair*" } \\
\text { OR "cognitive decline") OR TI (dementia OR "cognitive } \\
\text { dysfunction" OR "functional decline" OR "functional limit*" OR } \\
\text { "physical decline" OR "physical limit*" OR "functional impair*" } \\
\text { OR "cognitive impair*" OR "cognitive decline") }\end{array}$ & Search modes - Boolean/Phrase & 193,129 \\
\hline $\mathrm{S} 1$ & $\begin{array}{l}\text { MH "Spouses" OR MH "Siblings" OR MH "Guardianship, Legal" } \\
\text { OR MH "Family+" OR MH "Extended Family+" OR MH } \\
\text { "Caregivers" OR MH "Adult Children" OR AB (surrogate* OR } \\
\text { relative* OR child OR children OR husband* OR wife OR wives } \\
\text { OR niece* OR nephew* OR grandchild OR grandchildren OR } \\
\text { "Caregiver*" OR "next of kin*" OR carer*) OR TI (surrogate* OR } \\
\text { relative* OR child OR children OR husband* OR wife OR wives } \\
\text { OR niece* OR nephew* OR grandchild OR grandchildren OR } \\
\text { "Caregiver*" OR "next of kin*" OR carer*) }\end{array}$ & Search modes - Boolean/Phrase & 826,851 \\
\hline
\end{tabular}




\section{Joanna Briggs Institute (Searched on $5^{\text {th }}$ November 2020)}

\begin{tabular}{|c|c|c|c|}
\hline Search ID & Search Terms & Search Options & Actions \\
\hline S5 & S1 AND S2 AND S3 AND S4 & $\begin{array}{l}\text { Search modes - } \\
\text { Boolean/Phrase }\end{array}$ & 332 \\
\hline S4 & $\begin{array}{l}\text { DE ("Education" OR "Educational Counseling" OR "Social Support" OR } \\
\text { "Counseling" OR "Mindfulness-Based Interventions" OR "Behavior Therapy" } \\
\text { OR "Cognitive Therapy" OR "Psychoeducation") OR AB ("Training Program*” } \\
\text { OR "Educational Activit*” OR “information" OR "Teach-Back Communication" } \\
\text { OR "Psychosocial support*” OR "psychoeducation*” OR “psycho-education*”) } \\
\text { OR TI ("Training Program*” OR "Educational Activit*” OR “information" OR } \\
\text { "Teach-Back Communication" OR "Psychosocial support*” OR } \\
\text { "psychoeducation*” OR "psycho-education*”) }\end{array}$ & $\begin{array}{l}\text { Search modes - } \\
\text { Boolean/Phrase }\end{array}$ & 634,316 \\
\hline S3 & $\begin{array}{l}\text { AB ("Homes for the Aged" OR "residential care" OR "nursing home*" OR } \\
\text { "residential care home*” OR "long term facilt*”) OR TI ("Homes for the Aged" } \\
\text { OR "residential care" OR "nursing home*" OR "residential care home*" OR } \\
\text { "long term facilt*") OR DE ("Nursing Homes" OR "Long Term Care" OR } \\
\text { "Residential Care Institutions") }\end{array}$ & $\begin{array}{l}\text { Search modes - } \\
\text { Boolean/Phrase }\end{array}$ & 28,536 \\
\hline S2 & 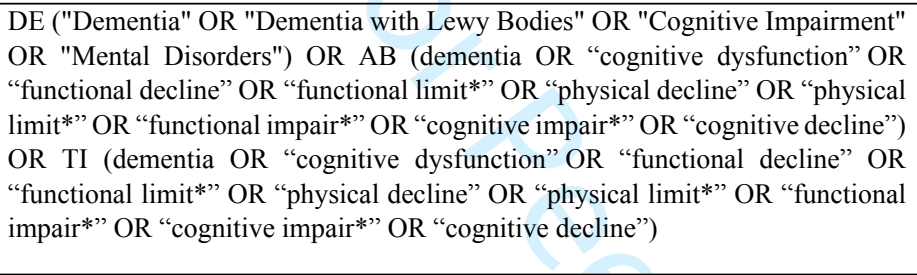 & $\begin{array}{l}\text { Search modes - } \\
\text { Boolean/Phrase }\end{array}$ & 249,789 \\
\hline S1 & $\begin{array}{l}\text { AB (relatives OR child OR children OR husband* OR wife OR wives OR niece* } \\
\text { OR nephew* OR grandchild OR grandchildren OR carer* OR relative* OR next } \\
\text { of kin*) OR TI (relatives OR child OR children OR husband* OR wife OR wives } \\
\text { OR niece* OR nephew* OR grandchild OR grandchildren OR carer* OR } \\
\text { relative* OR next of kin*) OR DE ("Family" OR "Caregivers" OR "Extended } \\
\text { Family" OR "Surrogate Parents (Humans)" OR "Parents" OR "Guardianship" OR } \\
\text { "Siblings") }\end{array}$ & $\begin{array}{l}\text { Search modes - } \\
\text { Boolean/Phrase }\end{array}$ & 981,370 \\
\hline
\end{tabular}

\section{Scopus (Searched on $5^{\text {th }}$ November 2020)}

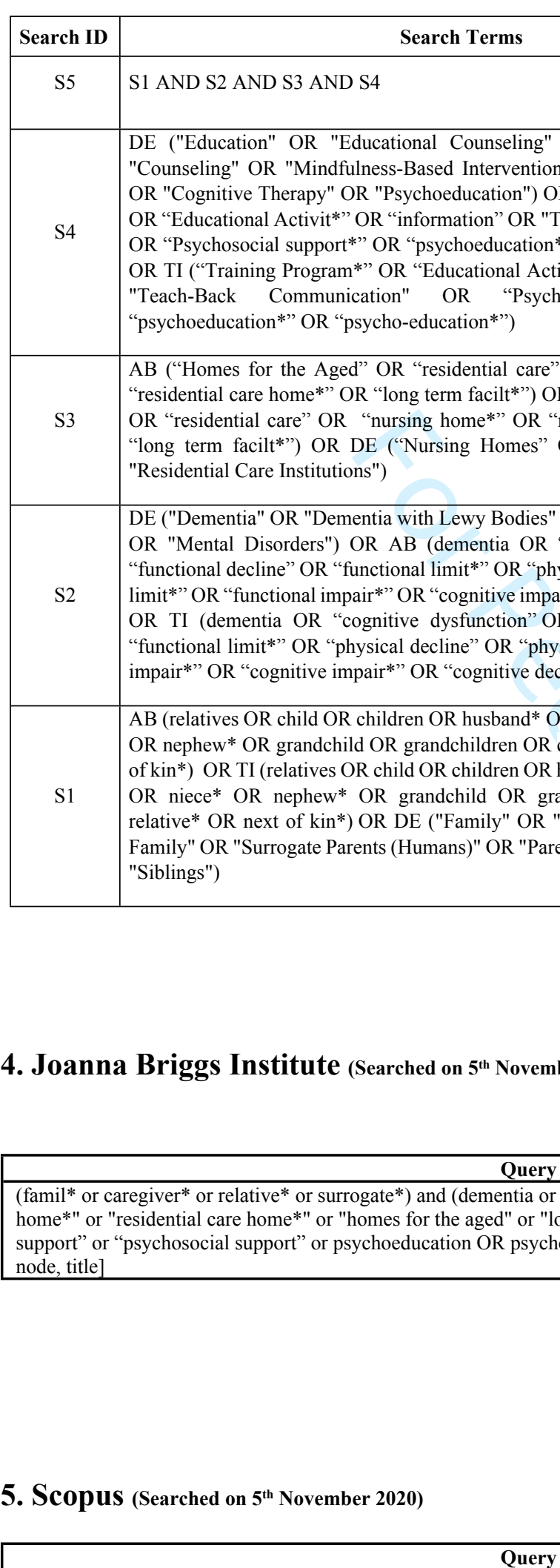

\begin{tabular}{|c|c|}
\hline Query & Items \\
\hline $\begin{array}{l}\text { TITLE-ABS-KEY (famil* OR caregiver* OR relative* OR surrogate*) AND (dementia or "cognitive impair*" or } \\
\text { "cognitive decline") and ("nursing home*" OR "residential care home*" OR "homes for the aged" OR "long term } \\
\text { facilit*") AND (education or counseling or "social support" or "psychosocial support" or psychoeducation OR psycho- } \\
\text { education) }\end{array}$ & 611 \\
\hline
\end{tabular}




\section{Appendix 3: Assessment of methodological quality}

Appendix 3a: Assessment of methodological quality: survey designs reporting frequencies/proportions ${ }^{\mathrm{a}}$

\begin{tabular}{|c|c|c|c|c|c|c|c|c|c|c|}
\hline $\begin{array}{l}\text { Author(s), } \\
\text { year (code) }\end{array}$ & $\begin{array}{l}\text { C1. Sample } \\
\text { frame } \\
\text { appropriate to } \\
\text { address the } \\
\text { target } \\
\text { population }\end{array}$ & $\begin{array}{l}\text { C2. Study } \\
\text { participants } \\
\text { sampled in an } \\
\text { appropriate way }\end{array}$ & $\begin{array}{l}\text { C3. Sample } \\
\text { size adequate }\end{array}$ & $\begin{array}{l}\text { C4. Study } \\
\text { subjects and } \\
\text { the setting } \\
\text { described in } \\
\text { detail }\end{array}$ & $\begin{array}{l}\text { C5. Data analysis } \\
\text { conducted with } \\
\text { sufficient } \\
\text { coverage of the } \\
\text { identified sample }\end{array}$ & $\begin{array}{l}\text { C6. Valid } \\
\text { methods used } \\
\text { for the } \\
\text { identification of } \\
\text { the condition }\end{array}$ & $\begin{array}{l}\text { C7. Condition } \\
\text { measured in a } \\
\text { standard, } \\
\text { reliable way for } \\
\text { all participants }\end{array}$ & $\begin{array}{l}\text { C8. } \\
\text { Appropriate } \\
\text { statistical } \\
\text { analysis }\end{array}$ & $\begin{array}{l}\text { C9. Response rate } \\
\text { adequate or } \\
\text { appropriate } \\
\text { management of } \\
\text { low response rate }\end{array}$ & $\begin{array}{l}\text { Quality } \\
\text { appraisal }^{\mathrm{a}}\end{array}$ \\
\hline $\begin{array}{l}\text { Arcand et } \\
\text { al., } 2013 \\
(\mathrm{H})^{50}\end{array}$ & $\mathrm{~N}$ & $\mathrm{Y}$ & $\mathrm{Y}$ & $\mathrm{Y}$ & $\mathrm{Y}$ & $\mathrm{Y}$ & $\mathrm{Y}$ & $\mathrm{Y}$ & $\mathrm{N}$ & $7 / 9$ \\
\hline $\begin{array}{l}\text { van der } \\
\text { Steen, } \\
\text { Arcand, et } \\
\text { al., } 2012 \\
\text { (I) }{ }^{51}\end{array}$ & Y & $\mathrm{Y}$ & $\mathrm{Y}$ & $\mathrm{Y}$ & $\mathrm{Y}$ & $\mathrm{Y}$ & $\mathrm{Y}$ & $\mathrm{Y}$ & $\mathrm{Y}$ & $9 / 9$ \\
\hline $\begin{array}{l}\text { van der } \\
\text { Steen, de } \\
\text { Grass, et } \\
\text { al., } 2011 \\
(\mathrm{~K})^{46}\end{array}$ & $\bar{Y}$ & $\mathrm{~N}$ & $\bar{Y}$ & $\bar{Y}$ & $\bar{Y}$ & $\mathrm{Y}$ & $\overline{\mathrm{Y}}$ & $\mathrm{N}$ & $\bar{Y}$ & $7 / 9$ \\
\hline $\begin{array}{l}\text { van der } \\
\text { Steen, } \\
\text { Toscani, et } \\
\text { al., } 2011 \\
\text { (D) } \\
\end{array}$ & Y & $\mathrm{Y}$ & Y & Y & $\mathrm{Y}$ & $\mathrm{Y}$ & Y & $\mathrm{Y}$ & $\mathrm{Y}$ & $9 / 9$ \\
\hline
\end{tabular}

Abbreviations: C, criteria; JBI, Joanna Briggs Institute; N, no; NA, not applicable; U, unclear; Y, yes.

${ }^{a}$ According to the JBI critical appraisal tool for studies reporting prevalence data. Munn Z, Moola S, Lisy K, Riitano D, Tufanaru C. Methodological guidance for systematic reviews of observational epidemiological studies reporting prevalence and incidence data. Int J Evid Based Healthc. 2015;13(3):147-153. 
Appendix 3b: Assessment of methodological quality: randomized controlled trials ${ }^{\mathrm{a}}$

\begin{tabular}{|c|c|c|c|c|c|c|c|c|c|c|c|c|c|c|}
\hline $\begin{array}{l}\text { Author(s), } \\
\text { year } \\
\text { (code) }\end{array}$ & $\begin{array}{l}\text { C1. True } \\
\text { randomization } \\
\text { used for } \\
\text { assignment of } \\
\text { participants to } \\
\text { treatment } \\
\text { groups }\end{array}$ & $\begin{array}{l}\mathrm{C} 2 . \\
\text { Allocation } \\
\text { to } \\
\text { treatment } \\
\text { groups } \\
\text { concealed }\end{array}$ & $\begin{array}{l}\text { C3. } \\
\text { Treatment } \\
\text { groups } \\
\text { similar at } \\
\text { the } \\
\text { baseline }\end{array}$ & $\begin{array}{l}\text { C4. } \\
\text { Participants } \\
\text { blind to } \\
\text { treatment } \\
\text { assignment }\end{array}$ & $\begin{array}{l}\text { C5. Those } \\
\text { delivering } \\
\text { treatment } \\
\text { blind to } \\
\text { treatment } \\
\text { assignment }\end{array}$ & $\begin{array}{l}\text { C6. } \\
\text { Outcomes } \\
\text { assessors } \\
\text { blind to } \\
\text { treatment } \\
\text { assignment }\end{array}$ & $\begin{array}{l}\text { C7. } \\
\text { Treatment } \\
\text { groups } \\
\text { treated } \\
\text { identically } \\
\text { other than } \\
\text { the } \\
\text { intervention } \\
\text { of interest }\end{array}$ & $\begin{array}{l}\text { C8. } \\
\text { Follow up } \\
\text { complete } \\
\text { or } \\
\text { differences } \\
\text { between } \\
\text { groups } \\
\text { described } \\
\text { and } \\
\text { analyzed if } \\
\text { not } \\
\text { complete }\end{array}$ & $\begin{array}{l}\text { C9. } \\
\text { Participants } \\
\text { analyzed in } \\
\text { the groups } \\
\text { to which } \\
\text { they were } \\
\text { randomized }\end{array}$ & $\begin{array}{l}\text { C10. } \\
\text { Outcomes } \\
\text { measured } \\
\text { in the } \\
\text { same way } \\
\text { for } \\
\text { treatment } \\
\text { groups }\end{array}$ & $\begin{array}{l}\text { C11. } \\
\text { Outcomes } \\
\text { measured } \\
\text { in a } \\
\text { reliable } \\
\text { way }\end{array}$ & $\begin{array}{l}\text { C12. } \\
\text { Appropriate } \\
\text { statistical } \\
\text { analysis } \\
\text { used }\end{array}$ & $\begin{array}{l}\text { C13. } \\
\text { Trial } \\
\text { design } \\
\text { appropriate } \\
\text { and any } \\
\text { deviations } \\
\text { from the } \\
\text { standard } \\
\text { design } \\
\text { accounted } \\
\text { for in the } \\
\text { conduct } \\
\text { and } \\
\text { analysis of } \\
\text { the trial }\end{array}$ & $\begin{array}{l}\text { Quality } \\
\text { appraisal }\end{array}$ \\
\hline $\begin{array}{l}\text { Ducharme, } \\
\text { Levesque, } \\
\text { Giroux, et } \\
\text { al., } 2005 \\
(\mathrm{G})^{37}\end{array}$ & $\mathrm{U}$ & $\mathrm{U}$ & $\mathrm{N}$ & $\mathrm{NA}$ & $\mathrm{Y}$ & $\mathrm{U}$ & $\mathrm{Y}$ & $\mathrm{Y}$ & $\mathrm{N}$ & $\mathrm{Y}$ & $\mathrm{Y}$ & $\mathrm{N}$ & $\mathrm{Y}$ & $6 / 12$ \\
\hline $\begin{array}{l}\text { Ducharme, } \\
\text { Levesque, } \\
\text { Lachance, } \\
\text { et al., } \\
2005(\mathrm{~F})^{48}\end{array}$ & $\mathrm{U}$ & $\mathrm{U}$ & $\mathrm{N}$ & $\overline{\mathrm{NA}}$ & $\mathrm{Y}$ & $\mathrm{U}$ & $\mathrm{Y}$ & $\mathrm{Y}$ & $\mathrm{N}$ & $\mathrm{Y}$ & $\mathrm{Y}$ & $\mathrm{N}$ & $\mathrm{Y}$ & $6 / 12$ \\
\hline $\begin{array}{l}\text { Reinhardt } \\
\text { et al., } \\
2014(\mathrm{C})^{44}\end{array}$ & $\mathrm{U}$ & $\mathrm{U}$ & $\mathrm{Y}$ & $\overline{\mathrm{NA}}$ & NA & $\mathrm{Y}$ & $\mathrm{Y}$ & $\mathrm{Y}$ & $\mathrm{N}$ & $\mathrm{Y}$ & $\mathrm{Y}$ & $\mathrm{Y}$ & $\mathrm{Y}$ & $8 / 11$ \\
\hline
\end{tabular}

${ }^{a}$ According to the JBI critical appraisal tool for randomized controlled trials. Tufanaru C, Munn Z, Aromataris E, Campbell J, Hopp L. Chapter 3: Systematic reviews of effectiveness. In: Aromataris E, Munn Z (Editors) JBI Manual for Evidence Synthesis. JBI, 2020. 
Appendix 3c: Assessment of methodological quality: qualitative studies ${ }^{\text {a }}$

\begin{tabular}{|c|c|c|c|c|c|c|c|c|c|c|c|}
\hline $\begin{array}{l}\text { Author(s), } \\
\text { year (code) }\end{array}$ & $\begin{array}{l}\mathrm{C} 1 . \\
\text { Congruity in } \\
\text { philosophical } \\
\text { perspective }\end{array}$ & $\begin{array}{l}\mathrm{C} 2 \text {. } \\
\text { Congruity } \\
\text { in research } \\
\text { objective }\end{array}$ & $\begin{array}{l}\text { C3. } \\
\text { Congruity } \\
\text { in methods } \\
\text { used to } \\
\text { collect data }\end{array}$ & $\begin{array}{l}\text { C4. } \\
\text { Congruity } \\
\text { in data } \\
\text { analysis }\end{array}$ & $\begin{array}{l}\text { C5. } \\
\text { Congruity in } \\
\text { interpretation of } \\
\text { the results }\end{array}$ & $\begin{array}{l}\text { C6. } \\
\text { Cultural or } \\
\text { theoretical } \\
\text { orientation of } \\
\text { the } \\
\text { researcher(s) }\end{array}$ & $\begin{array}{l}\text { C7. } \\
\text { Potential } \\
\text { influence } \\
\text { of the } \\
\text { researcher } \\
\text { on the } \\
\text { research } \\
\text { and vice- } \\
\text { versa }\end{array}$ & $\begin{array}{l}\text { C8. } \\
\text { Representativeness of } \\
\text { the participants' } \\
\text { voices }\end{array}$ & $\begin{array}{l}\text { C9. } \\
\text { Ethical } \\
\text { approval }\end{array}$ & $\begin{array}{l}\text { C10. } \\
\text { Conclusions } \\
\text { drawn from } \\
\text { the analysis }\end{array}$ & $\begin{array}{l}\text { Quality } \\
\text { appraisal }^{\text {a }}\end{array}$ \\
\hline $\begin{array}{l}\text { Saini et al., } \\
2016(\mathrm{~A})^{43}\end{array}$ & $\mathrm{Y}$ & $\mathrm{Y}$ & $\mathrm{Y}$ & $\mathrm{Y}$ & $\mathrm{Y}$ & $\mathrm{Y}$ & $\mathrm{Y}$ & $\mathrm{Y}$ & $\mathrm{Y}$ & $\mathrm{Y}$ & $10 / 10$ \\
\hline $\begin{array}{l}\text { Stirling et } \\
\text { al., } 2014 \\
\text { (B) }\end{array}$ & $\mathrm{Y}$ & $\bar{Y}$ & $\mathrm{Y}$ & & $\mathrm{Y}$ & $\mathrm{N}$ & $\mathrm{N}$ & $\mathrm{Y}$ & $\mathrm{Y}$ & $\mathrm{Y}$ & $8 / 10$ \\
\hline
\end{tabular}

Abbreviations: C, criteria; JBI-QARI, Joanna Briggs Institute - Quality Assessment Review Instrument; N, no; NA, not applicable; U, unclear; Y, yes.

${ }^{a}$ According to the JBI-QARI critical appraisal tool. Lockwood C, Munn Z, Porritt K. Qualitative research synthesis: methodological guidance for systematic reviewers utilizing meta-aggregation. Int J Evid Based Healthc. 2015;13(3):179-187.

Appendix 3d: Assessment of methodological quality: case reports ${ }^{\mathrm{a}}$

\begin{tabular}{|c|c|c|c|c|c|c|c|c|c|}
\hline $\begin{array}{l}\text { Author(s), } \\
\text { year (code) }\end{array}$ & $\begin{array}{l}\text { C1. Patient's } \\
\text { demographic } \\
\text { characteristics } \\
\text { clearly described }\end{array}$ & $\begin{array}{l}\text { C2. Patient's } \\
\text { history clearly } \\
\text { described and } \\
\text { presented as a } \\
\text { timeline }\end{array}$ & $\begin{array}{l}\text { C3. Current } \\
\text { clinical condition } \\
\text { of the patient on } \\
\text { presentation } \\
\text { clearly described }\end{array}$ & $\begin{array}{l}\text { C4. Diagnostic } \\
\text { tests or } \\
\text { assessment } \\
\text { methods and the } \\
\text { results clearly } \\
\text { described }\end{array}$ & $\begin{array}{l}\text { C5. Intervention(s) or } \\
\text { treatment } \\
\text { procedure(s) clearly } \\
\text { described }\end{array}$ & $\begin{array}{l}\text { C6. } \\
\text { Post-intervention } \\
\text { clinical condition } \\
\text { clearly described }\end{array}$ & $\begin{array}{l}\text { C7. Adverse events } \\
\text { (harms) or } \\
\text { unanticipated } \\
\text { events identified } \\
\text { and described }\end{array}$ & $\begin{array}{l}\text { C8. } \\
\text { Takeaway } \\
\text { lessons } \\
\text { provided }\end{array}$ & $\begin{array}{l}\text { Quality } \\
\text { appraisala }\end{array}$ \\
\hline $\begin{array}{l}\text { Sabat et al., } \\
2010(\mathrm{~J})^{45}\end{array}$ & $\mathrm{Y}$ & $\mathrm{Y}$ & NA & $\mathrm{Y}$ & $\mathrm{Y}$ & $\mathrm{Y}$ & $\mathrm{Y}$ & $\mathrm{Y}$ & $7 / 7$ \\
\hline
\end{tabular}

Abbreviations: C, criteria; JBI, Joanna Briggs Institute; N, no; NA, not applicable; U, unclear; Y, yes.

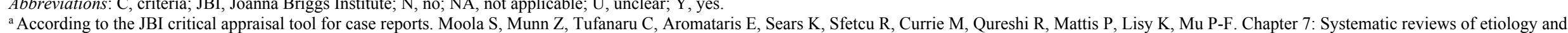
risk. In: Aromataris E, Munn Z (Editors). JBI Manual for Evidence Synthesis. JBI, 2020. 


\section{Appendix 4: Assessment of the level of evidence}

Appendix 4a: Assessment of the level of evidence: quantitative studies ${ }^{\mathrm{a}}$

\begin{tabular}{|c|c|c|c|c|c|c|c|c|c|c|}
\hline \multirow[b]{2}{*}{$\begin{array}{l}\text { Author(s), } \\
\text { year (code) }\end{array}$} & \multirow[b]{2}{*}{$\begin{array}{c}\text { Pre- } \\
\text { ranking }\end{array}$} & \multicolumn{5}{|c|}{ Reasons to downgrade the evidence quality } & \multicolumn{3}{|c|}{ Reasons to upgrade the evidence quality } & \multirow[b]{2}{*}{$\begin{array}{c}\text { GRADE } \\
\text { assessment }\end{array}$} \\
\hline & & Risk of bias & Inconsistency & Indirectness & Imprecision & $\begin{array}{l}\text { Publication } \\
\text { bias }\end{array}$ & $\begin{array}{l}\text { Large magnitude } \\
\text { of effect }\end{array}$ & $\begin{array}{l}\text { Dose } \\
\text { response }\end{array}$ & $\begin{array}{l}\text { Effect of all plausible } \\
\text { confounding factors }\end{array}$ & \\
\hline $\begin{array}{l}\text { Arcand et al., } \\
2013(\mathrm{H})^{50}\end{array}$ & Low & $\leftrightarrow$ & $\leftrightarrow$ & $\leftrightarrow$ & $\leftrightarrow$ & $\leftrightarrow$ & $\leftrightarrow$ & $\leftrightarrow$ & $\leftrightarrow$ & $\bullet \bullet \circ \circ$ Low \\
\hline $\begin{array}{l}\text { Ducharme, } \\
\text { Levesque, } \\
\text { Giroux, et al., } \\
2005(\mathrm{G})^{37}\end{array}$ & High & $\downarrow$ & $\leftrightarrow$ & $\leftrightarrow$ & $\leftrightarrow$ & $\leftrightarrow$ & $\leftrightarrow$ & $\leftrightarrow$ & $\leftrightarrow$ & $\bullet \bullet \bullet \circ$ Moderate \\
\hline $\begin{array}{l}\text { Ducharme, } \\
\text { Levesque, } \\
\text { Lachance, et } \\
\text { al., } 2005(\mathrm{~F})^{48}\end{array}$ & High & $\downarrow$ & $\leftrightarrow$ & $\leftrightarrow$ & & $\leftrightarrow$ & $\leftrightarrow$ & $\leftrightarrow$ & $\leftrightarrow$ & $\bullet \bullet \bullet \circ$ Moderate \\
\hline $\begin{array}{l}\text { Moore et al., } \\
2020(\mathrm{E})^{42}\end{array}$ & Low & $\leftrightarrow$ & $\leftrightarrow$ & $\leftrightarrow$ & $\leftrightarrow$ & $\leftrightarrow$ & $\leftrightarrow$ & $\leftrightarrow$ & $\leftrightarrow$ & $\bullet \bullet \circ \circ$ Low \\
\hline $\begin{array}{l}\text { Reinhardt et } \\
\text { al., } 2014(\mathrm{C})^{44}\end{array}$ & High & $\downarrow$ & $\leftrightarrow$ & $\leftrightarrow$ & $\leftrightarrow$ & $\leftrightarrow$ & $\leftrightarrow$ & $\leftrightarrow$ & $\leftrightarrow$ & $\bullet \bullet \bullet \circ$ Moderate \\
\hline $\begin{array}{l}\text { van der Steen, } \\
\text { Arcand, et al., } \\
2012(\mathrm{I})^{51}\end{array}$ & Low & $\leftrightarrow$ & $\leftrightarrow$ & $\leftrightarrow$ & $\leftrightarrow$ & $\leftrightarrow$ & $\uparrow \uparrow$ & $\leftrightarrow$ & $\uparrow$ & $\bullet \bullet \bullet \bullet$ High \\
\hline $\begin{array}{l}\text { van der Steen, } \\
\text { de Grass, et al., } \\
2011(\mathrm{~K})^{46}\end{array}$ & Low & $\leftrightarrow$ & $\leftrightarrow$ & $\leftrightarrow$ & $\leftrightarrow$ & $\leftrightarrow$ & $\leftrightarrow$ & $\leftrightarrow$ & $\leftrightarrow$ & $\bullet \bullet \circ \circ$ Low \\
\hline $\begin{array}{l}\text { van der Steen, } \\
\text { Toscani, et al., } \\
2011 \text { (D) })^{47}\end{array}$ & Low & $\leftrightarrow$ & $\leftrightarrow$ & $\leftrightarrow$ & $\leftrightarrow$ & $\leftrightarrow$ & $\uparrow \uparrow$ & $\leftrightarrow$ & $\leftrightarrow$ & $\bullet \bullet \bullet \bullet$ High \\
\hline
\end{tabular}

Note. Acco low to very low. This baseline rating can then be adjusted (downgraded or upgraded) after considering 8 assessment criteria and making a judgement about quality based on these.

${ }^{a}$ Ryan R, Hill S. How to GRADE the quality of the evidence. Cochrane Consumers and Communication Group, 2016. Available at http://cccrg.cochrane.org/author-resources. Version 3.0 December 2016.

$\leftrightarrow$ ranking unchanged

$\uparrow$ ranking upgraded one level

$\uparrow \uparrow$ ranking upgraded two levels

$\downarrow$ ranking downgraded one level 
Appendix 4b: Assessment of the level of evidence: qualitative studies ${ }^{\mathrm{a}}$

\begin{tabular}{|c|c|c|c|c|c|c|}
\hline $\begin{array}{l}\text { Author(s), } \\
\text { year (code) }\end{array}$ & Type of research & Pre-ranking & Dependability & Credibility & ConQual & Comments \\
\hline $\begin{array}{l}\text { Sabat et al., } \\
2010(J)^{45}\end{array}$ & Qualitative & High & $\leftrightarrow$ & $\leftrightarrow$ & $\begin{array}{l}\bullet \bullet \bullet \bullet \\
\text { High }\end{array}$ & $\begin{array}{l}\text { Dependability unchanged since } 4-5 \text { criteria were positive } \\
\text { Credibility unchanged since all findings were unequivocal }\end{array}$ \\
\hline $\begin{array}{l}\text { Saini et al., } \\
2016(\mathrm{~A})^{43}\end{array}$ & Qualitative & High & $\leftrightarrow$ & $\leftrightarrow$ & $\begin{array}{lll}\bullet \bullet \bullet \\
\text { High }\end{array}$ & $\begin{array}{l}\text { Dependability unchanged since } 4-5 \text { criteria were positive } \\
\text { Credibility unchanged since all findings were unequivocal }\end{array}$ \\
\hline $\begin{array}{l}\text { Stirling et al., } \\
2014(\mathrm{~B})^{49}\end{array}$ & Qualitative & High & $\downarrow$ & $\leftrightarrow$ & $\begin{array}{c}\bullet \bullet \bullet \circ \\
\text { Moderate }\end{array}$ & $\begin{array}{l}\text { Dependability downgraded one level as only } 2-3 \text { criteria were positive } \\
\text { Credibility unchanged since all findings were unequivocal }\end{array}$ \\
\hline
\end{tabular}

Note. According to the ConQual approach to establish confidence in qualitative evidence, all qualitative research studies start with a ranking of 'high' on a scale of high, moderate, low to very low. This ranking system then

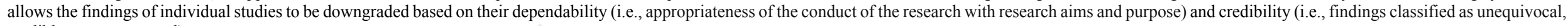
credible, or unsupported).

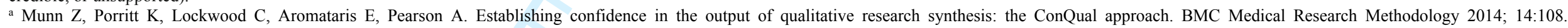
https://doi.org/10.1186/1471-2288-14-108.

$\leftrightarrow$ ranking unchanged

$\downarrow$ ranking downgraded one level

Appendix 4c: Assessment of the level of evidence: integrated findings ${ }^{\mathrm{a}}$

\begin{tabular}{|c|c|c|c|c|c|}
\hline Integrated findings & Type of research & Dependability & Credibility & ConQual & Comments \\
\hline $\begin{array}{l}\text { 1. End-of-life dialogue should be ongoing and provide adequate } \\
\text { time and space for sensitive discussion to establish a family } \\
\text { caregivers-healthcare professionals partnership, promote shared } \\
\text { decision-making and improve the quality of family caregivers' } \\
\text { remaining time with their relative while offering emotional support }\end{array}$ & Qualitative & Moderate & High & $\begin{array}{l}\bullet \bullet \bullet \circ \\
\text { Moderate }\end{array}$ & $\begin{array}{l}\text { Dependability downgraded one level since two } 43,45 \\
\text { studies were ranked high and two }{ }^{43,45} \text { studies were } \\
\text { ranked moderate. }{ }^{48,49} \\
\begin{array}{l}\text { Credibility unchanged since all findings were } \\
\text { considered unequivocal }\end{array}\end{array}$ \\
\hline $\begin{array}{l}\text { 2. End-of-life discussions should be face-to-face and guided by } \\
\text { supporting written information whose provision may vary in timing } \\
\text { and way according to family caregivers' preferences and the } \\
\text { context }\end{array}$ & $\begin{array}{l}\text { Qualitative } \\
\text { Quantitative }\end{array}$ & Moderate & High & $\begin{array}{l}\bullet \bullet \bullet ० \\
\text { Moderate }\end{array}$ & $\begin{array}{l}\text { Dependability downgraded one level since three } 43,47,51 \\
\text { studies were ranked high, one }{ }^{49} \text { study was ranked } \\
\text { moderate, and three }{ }^{42,46,50} \text { studies were ranked low. } \\
\begin{array}{l}\text { Credibility unchanged since all findings were } \\
\text { considered unequivocal }\end{array}\end{array}$ \\
\hline $\begin{array}{l}\text { 3. Family caregivers should be offered tailored psychoeducational } \\
\text { programmes and/or regular family meetings about dementia care at } \\
\text { the end of life according to their specific information and emotional } \\
\text { needs to promote understanding about their relative's health } \\
\text { conditions, acceptance of the upcoming loss, and empowerment in } \\
\text { facing challenging end-of-life-related issues }\end{array}$ & $\begin{array}{l}\text { Qualitative } \\
\text { Quantitative }\end{array}$ & Moderate & High & $\begin{array}{l}\bullet \bullet \bullet \circ \\
\text { Moderate }\end{array}$ & $\begin{array}{l}\text { Dependability downgraded one level since two } \mathrm{o}^{43,45} \\
\text { studies were ranked high, three } 37,44,48 \text { studies were } \\
\text { ranked moderate, and one }{ }^{42} \text { study was ranked low. } \\
\text { Credibility unchanged since all findings were } \\
\text { considered unequivocal }\end{array}$ \\
\hline
\end{tabular}

Note. The integrated finding may be downgraded based on the aggregate level of dependability from across the included findings. Downgrading for credibility may occur when not all the findings included in an integrated finding are considered unequivocal.

${ }^{a}$ Munn Z, Porritt K, Lockwood C, Aromataris E, Pearson A. Establishing confidence in the output of qualitative research synthesis: the ConQual approach. BMC Medical Research Methodology 2014; 14:108. https://doi.org/10.1186/1471-2288-14-108. 